\title{
Identifying the reactive sites of hydrogen peroxide decomposition and hydroxyl radical formation on chrysotile asbestos surfaces
}

Martin Walter ${ }^{1}$, Walter D. C. Schenkeveld ${ }^{1,2^{*}}$, Gerald Geroldinger ${ }^{3}$, Lars Gille ${ }^{3}$, Michael Reissner ${ }^{4}$ and Stephan M. Kraemer ${ }^{1}$

\begin{abstract}
Background: Fibrous chrysotile has been the most commonly applied asbestos mineral in a range of technical applications. However, it is toxic and carcinogenic upon inhalation. The chemical reactivity of chrysotile fiber surfaces contributes to its adverse health effects by catalyzing the formation of highly reactive hydroxyl radicals ( $\left.\mathrm{HO}^{\circ}\right)$ from $\mathrm{H}_{2} \mathrm{O}_{2}$. In this Haber-Weiss cycle, Fe on the fiber surface acts as a catalyst: $\mathrm{Fe}^{3+}$ decomposes $\mathrm{H}_{2} \mathrm{O}_{2}$ to reductants that reduce surface $\mathrm{Fe}^{3+}$ to $\mathrm{Fe}^{2+}$, which is back-oxidized by $\mathrm{H}_{2} \mathrm{O}_{2}$ (Fenton-oxidation) to yield $\mathrm{HO}^{\text {: }}$. Chrysotile contains three structural Fe species: ferrous and ferric octahedral $\mathrm{Fe}$ and ferric tetrahedral $\mathrm{Fe}\left(\mathrm{Fe}^{3+}{ }_{\text {tet }}\right)$. Also, external Fe may adsorb or precipitate onto fiber surfaces. The goal of this study was to identify the Fe species on chrysotile surfaces that catalyze $\mathrm{H}_{2} \mathrm{O}_{2}$ decomposition and $\mathrm{HO}^{\circ}$ generation.

Results: We demonstrate that at the physiological $\mathrm{pH} 7.4 \mathrm{Fe}^{3+}$ tet on chrysotile surfaces substantially contributes to $\mathrm{H}_{2} \mathrm{O}_{2}$ decomposition and is the key structural Fe species catalyzing $\mathrm{HO}^{\circ}$ generation. After depleting Fe from fiber surfaces, a remnant fiber-related $\mathrm{H}_{2} \mathrm{O}_{2}$ decomposition mode was identified, which may involve magnetite impurities, remnant Fe or substituted redox-active transition metals other than Fe. Fe (hydr)oxide precipitates on chrysotile surfaces also contributed to $\mathrm{H}_{2} \mathrm{O}_{2}$ decomposition, but were per mole Fe substantially less efficient than surface $\mathrm{Fe}^{3+}$ tet. Fe added to chrysotile fibers increased $\mathrm{HO}^{\circ}$ generation only when it became incorporated and tetrahedrally coordinated into vacancy sites in the Si layer.

Conclusions: Our results suggest that at the physiological pH 7.4, oxidative stress caused by chrysotile fibers largely results from radicals produced in the Haber-Weiss cycle that is catalyzed by $\mathrm{Fe}^{3+}$ tet. The catalytic role of Fe ${ }^{3+}$ tet in radical generation may also apply to other pathogenic silicates in which $\mathrm{Fe}^{3+}$ tet is substituted, e.g. quartz, amphiboles and zeolites. However, even if these pathogenic minerals do not contain Fe, our results suggest that the mere presence of vacancy sites may pose a risk, as incorporation of external Fe into a tetrahedral coordination environment can lead to $\mathrm{HO}^{\circ}$ generation.
\end{abstract}

Keywords: Asbestos, Chrysotile, Haber-Weiss, Hydroxyl radical, Fenton, Tetrahedral iron, Mössbauer, EPR

\footnotetext{
* Correspondence: walter.schenkeveld@univie.ac.at

'Department of Environmental Geosciences, University of Vienna,

Althanstraße 14 (UZA II), 1090 Vienna, Austria

${ }^{2}$ Copernicus Institute of Sustainable Development, Faculty of Geosciences,

Utrecht University, Princetonlaan 8A, 3584, CB, Utrecht, the Netherlands

Full list of author information is available at the end of the article
}

(c) The Author(s). 2020 Open Access This article is distributed under the terms of the Creative Commons Attribution 4.0 International License (http://creativecommons.org/licenses/by/4.0/), which permits unrestricted use, distribution, and reproduction in any medium, provided you give appropriate credit to the original author(s) and the source, provide a link to the Creative Commons license, and indicate if changes were made. The Creative Commons Public Domain Dedication waiver (http://creativecommons.org/publicdomain/zero/1.0/) applies to the data made available in this article, unless otherwise stated. 


\section{Background}

The term asbestos refers to a heterogeneous group of five fibrous amphiboles and one fibrous serpentine mineral (chrysotile) [1, 2]. Due to its favorable properties such as a large tensile strength, heat resistance and noncombustibility, asbestos has been used in a variety of industrial applications [3], e.g. in thermal and electrical insulation, roofing, cement pipes and sheets, flooring and coatings $[4,5]$. However, respiratory exposure to asbestos minerals causes adverse health effects like pneumoconiosis, fibrosis of the lung, pleural plaques and effusions, carcinomas predominantly in the lung (but also in the larynx and ovaries) and mesotheliomas in the pleura and peritoneum $[2,4,6,7]$. Because of their carcinogenic potential, the WHO-IARC has classified all asbestos minerals as group 1 carcinogens [8]. More than 100,000 people die each year because of asbestos-related illnesses, mostly following occupational exposure [9]. Because of the intrinsic health hazard of asbestos, its use has been banned in European countries from the late 1980s onwards [10]. In northern American countries its use has not yet been banned [10] and in some Asian countries it even increases $[11,12]$.

Chrysotile $\left[\mathrm{Mg}_{3} \mathrm{Si}_{2} \mathrm{O}_{5}(\mathrm{OH})_{4}\right]$ accounts for more than 95\% of all historically used asbestos [13]. As a result, exposure to asbestos predominantly concerns chrysotile. Therefore, we have focused on this mineral in this study. Chrysotile asbestos consists of octahedral Mg hydroxide layers and tetrahedral Si layers which bundle together to a fiber with a $\mathrm{Mg}$ hydroxide layer at the surface [14, 15]. During petrogenesis, $\mathrm{Fe}$ is substituted into the crystal lattice (usually up to 2-4 wt\%) [16]. Ferrous and ferric $\mathrm{Fe}$ are found in the $\mathrm{Mg}$ layers $\left(\mathrm{Fe}^{3+}{ }_{\text {oct }}\right.$ and $\mathrm{Fe}^{2+}{ }_{\text {oct }}$, respectively), whereas in the Si layers, exclusively ferric Fe is found $\left(\mathrm{Fe}^{3+}{ }_{\text {tet }}\right)[17,18]$. Fe is by far the most abundant redox-active metal in chrysotile [16].

Weathering of chrysotile at circumneutral pH is commonly described as a layer-by-layer dissolution of alternating $\mathrm{Mg}$ and $\mathrm{Si}$ layers. $\mathrm{Mg}$ layers at the fiber surface dissolve within hours, whereas exposed Si layers dissolve much slower and therefore determine the overall dissolution rate $[19,20]$. However, enhanced dissolution of $\mathrm{Fe}^{3+}$ tet from the $\mathrm{Si}$ layer by ligands like the siderophore desferrioxamine-B (DFOB) increases the $\mathrm{Si}$ dissolution rate, presumably through the formation of vacancy sites in the Si layer that labilize it [21].

Asbestos-induced pathologies can be linked to its high persistence in vivo [7, 22, 23], its fibrous morphology and the surface chemistry of the fibers [2, 7]. Asbestos fibers lodged in lung or pleural tissue induce continuous, yet unsuccessful attempts of macrophages and neutrophils to phagocytose the fibers - a process called frustrated phagocytosis. During this process, enzymatically formed reactive oxygen species (ROS) like hydrogen peroxide $\left(\mathrm{H}_{2} \mathrm{O}_{2}\right)$ and superoxide anions $\left(\mathrm{O}_{2}{ }^{{ }^{--}}\right)$are released into the immediate extracellular environment [7]. Both exhibit a low potency for cellular damage under homeostasis [24] and can be enzymatically detoxified. At elevated concentrations $\mathrm{H}_{2} \mathrm{O}_{2}$ and $\mathrm{O}_{2}{ }^{*-}$ may, however, interact with Fe on the fiber surface. This interaction induces cyclical redox reactions generating hydroxyl radicals $\left(\mathrm{HO}^{*}\right)$, which have a high potency to damage DNA, proteins and lipids [2, 24-27]. In this Haber-Weiss cycle, Fe acts as a catalyst: $\mathrm{Fe}^{3+}$ is reduced by $\mathrm{O}_{2}{ }^{--}$to $\mathrm{Fe}^{2+}$, which is back-oxidized by $\mathrm{H}_{2} \mathrm{O}_{2}$ in the so-called Fenton reaction, yielding $\mathrm{Fe}^{3+}$ and $\mathrm{HO}^{\circ}[2,28]$. In the presence of $\mathrm{Fe}^{3+}, \mathrm{H}_{2} \mathrm{O}_{2}$ may decompose to hydroperoxyl $\left(\mathrm{HO}_{2}{ }^{\circ}\right)$, which can either directly reduce $\mathrm{Fe}^{3+}$ to $\mathrm{Fe}^{2+}$ or decompose to the even stronger reductant, $\mathrm{O}_{2}{ }^{--}$[29].

Despite the important role of $\mathrm{H}_{2} \mathrm{O}_{2}$ and its degradation products in Fe redox cycling at the chrysotile fiber surface, $\mathrm{H}_{2} \mathrm{O}_{2}$ decomposition by asbestos has only been assessed in a limited number of studies [30-32]. An involvement of the Fenton and Haber-Weiss pathways in $\mathrm{H}_{2} \mathrm{O}_{2}$ decomposition by asbestos was demonstrated by Eberhardt et al. (1985) [30]. Furthermore, Fubini et al. (1995) [31] assessed $\mathrm{H}_{2} \mathrm{O}_{2}$ decomposition for various $\mathrm{Fe}$ containing minerals. They found that $\mathrm{H}_{2} \mathrm{O}_{2}$ decomposition rates by chrysotile and crocidolite were comparable, yet smaller than by magnetite and substantially larger than by hematite.

$\mathrm{H}_{2} \mathrm{O}_{2}$ decomposition by chrysotile partly occurs through Fenton reactions involving Fe surface species [2, 25, 33]. However, not all Fe surface species are equally Fenton-active or have an equal potential to form hydroxyl radicals. Fubini et al. (1995) [31] demonstrated that $\mathrm{Fe}^{2+}$ oct on chrysotile surfaces does not play a substantial role in $\mathrm{HO}^{*}$ generation. Recently, Walter et al. (2019) suggested that per mole Fe the potential to generate $\mathrm{HO}^{*}$ is substantially larger for surface exposed $\mathrm{Fe}^{3+}$ tet than for $\mathrm{Fe}_{\text {oct }}$ [21]. Furthermore, $\mathrm{Fe}^{3+}$ tet is the only $\mathrm{Fe}$ surface species in chrysotile that remains Fenton-active during long-term dissolution (weeks) at circumneutral $\mathrm{pH}$, because the Si layer in which it is incorporated dissolves slowly, whereas $\mathrm{Fe}_{\text {oct }}$ in the readily dissolving $\mathrm{Mg}$ layers rapidly precipitates to Fenton-inactive Fe (hydr)oxide minerals [21]. Depletion of all Fe surface species (including $\mathrm{Fe}^{3+}{ }_{\text {tet }}$ ) from chrysotile surfaces by ligands like DFOB decreased the radical yield of the fibers, almost to background values [21, 33]. Apart from structural Fe, also external Fe that associates with surfaces of asbestos (or other silicates) may generate ROS and increase oxidative stress in vivo and in vitro [2, 34-37].

To our knowledge, the relation between Fe speciation at chrysotile fiber surfaces and $\mathrm{H}_{2} \mathrm{O}_{2}$ decomposition rates has not yet been established. Also, the relation between the speciation of external Fe after associating with the chrysotile fiber surface and the change in radical 
yield and $\mathrm{H}_{2} \mathrm{O}_{2}$ decomposition rate of the fibers has not been explored previously. Hence, the current understanding of which $\mathrm{Fe}$ species at the chrysotile surface participate in the prerequisite step of the first stage $\left(\mathrm{H}_{2} \mathrm{O}_{2}\right.$ decomposition to reductants), and in the second stage (Fenton oxidation) of the Haber-Weiss cycle is incomplete. Establishing the reactive sites of $\mathrm{H}_{2} \mathrm{O}_{2}$ decomposition and $\mathrm{HO}^{\circ}$ generation on chrysotile surfaces is important in assessing the overall redox reactivity of chrysotile asbestos, which is a major determinant in its pathogenicity $[25,38]$. In this study we addressed this knowledge gap.

We hypothesize that $\mathrm{H}_{2} \mathrm{O}_{2}$ is decomposed, either by structural $\mathrm{Fe}^{3+}{ }_{\text {tet }}$ in exposed $\mathrm{Si}$ layers of the dissolving fibers, or by secondary Fe minerals precipitated on the fiber surface. The precipitated Fe may originate from external sources or from fiber dissolution during which structural $\mathrm{Fe}$ is released. Furthermore, we hypothesize that external $\mathrm{Fe}$ only substantially contributes to the $\mathrm{HO}^{*}$ yield of chrysotile fibers when it becomes tetrahedrally coordinated by incorporation into a Si layer. The rationale for this hypothesis is the high potential of surface $\mathrm{Fe}^{3+}{ }_{\text {tet }}$ for generating $\mathrm{HO}^{*}$ [21], compared to the low potential of $\mathrm{Fe}$ (hydr)oxides [37] precipitated on chrysotile surfaces. Finally, we hypothesize that chrysotile fibers with surfaces depleted in Fe (e.g. due to preconditioning with a ligand) may still pose a health hazard if external Fe is incorporated into vacant surface sites in the Si layer.

The hypotheses were tested in batch incubation experiments. Samples were analyzed by ICP-OES (inductively coupled plasma optical emission spectrometry), UV-VISphotospectrometry, Mössbauer spectroscopy and EPR (electron paramagnetic resonance) spectroscopy.

\section{Methods}

\section{Chemical reagents and asbestos characterization}

All chemical reagents used in this study were at least pro analysis grade and were ordered from VWR (unless otherwise mentioned). Chrysotile asbestos was purchased from Shijiazhuang Mining IMP\&EXP Trade Co, China. The material was characterized by XRD-Rietveld phase analysis, Raman spectroscopy, BET specific surface area measurement, Mössbauer spectroscopy, fusion digestion and neutron activation analysis [21]. The BET specific surface area (SSA) of Shijiazhuang chrysotile fibers was $20.3 \mathrm{~m}^{2} \mathrm{~g}^{-1}$ (with a standard deviation of 0.9 $\left.\mathrm{m}^{2} \mathrm{~g}^{-1},[21]\right)$, and phase impurities were established by XRD-Rietveld analysis: Shijiazhuang chrysotile contains $86.4 \pm 4.6 \%$ chrysotile fibers, whereas phase impurities in the fiber material are brucite, talc, chlorite, magnetite, quartz and calcite [21]. Key results on the bulk of Shijiazhuang chrysotile are presented in Table 1: Shijiazhuang chrysotile asbestos contains $\approx 249 \mathrm{~g} \mathrm{~kg}^{-1} \mathrm{Mg}$ and
Table 1 Bulk characteristics of pristine Shijiazhuang chrysotile asbestos (previously reported in Walter et al. (2019) [21]). Values in round brackets represent standard deviations

\begin{tabular}{|c|c|c|c|}
\hline \multicolumn{4}{|c|}{ Bulk characteristics of chrysotile asbestos } \\
\hline Bulk composition: & & $\begin{array}{l}\text { Fusion digestion } \\
(n=15) \text { : }\end{array}$ & $\begin{array}{l}\mathrm{NAA}^{\mathrm{a}} \\
(n=2)\end{array}$ \\
\hline $\mathrm{Mg}$ & {$\left[\mathrm{g} \mathrm{kg}^{-1}\right]$} & $249(7)$ & \\
\hline Si & {$\left[\mathrm{g} \mathrm{kg}^{-1}\right]$} & $188(3)$ & \\
\hline $\mathrm{Fe}$ & {$\left[\mathrm{g} \mathrm{kg}^{-1}\right]$} & $19.0(1.4)$ & $21.4(0.3)$ \\
\hline $\mathrm{Al}$ & {$\left[\mathrm{g} \mathrm{kg}^{-1}\right]$} & $8.0(0.5)$ & \\
\hline Bulk Fe speciation: & & Mössbauer: & \\
\hline $\mathrm{Fe}^{2+}$ oct & {$[\%]$} & 38.4 & \\
\hline $\mathrm{Fe}^{3+}$ oct & {$[\%]$} & 54.6 & \\
\hline $\mathrm{Fe}^{3+}$ tet & {$[\%]$} & 7.0 & \\
\hline Total Fe in chrysotile ${ }^{b}$ & {$[\%]$} & 68.2 & \\
\hline
\end{tabular}

${ }^{\mathrm{a}}$ Neutron activation analysis

${ }^{\mathrm{b}}$ Remaining Fe (31.8\%) is in magnetite impurities

$\approx 188 \mathrm{~g} \mathrm{~kg}^{-1} \mathrm{Si}$; the stoichiometric $\mathrm{Mg} / \mathrm{Si}$ ratio is close to 1.5. Fe $\left(\approx 20 \mathrm{~g} \mathrm{~kg}^{-1}\right)$ and $\mathrm{Al}\left(\approx 8 \mathrm{~g} \mathrm{~kg}^{-1}\right)$ are the major substituents. Mössbauer analyses demonstrated that in pristine Shijiazhuang chrysotile asbestos, almost all Fe is substituted into the octahedral $\mathrm{Mg}$ layer $\left(\approx 55 \% \mathrm{Fe}^{3+}\right.$ oct and $\approx 38 \% \mathrm{Fe}^{2+}{ }_{\text {oct }}$ ), whereas only $7 \%$ is substituted into the tetrahedral Si layer (Table 1). Magnetite $(1.5 \pm 0.2 \%$ in Shijiazhuang chrysotile) hosts approximately $32 \%$ of the total bulk Fe (Table 1).

\section{Preparation of fiber suspensions}

All experiments were carried out in fiber suspensions with a fiber to solution ratio of $1 \mathrm{~g} \mathrm{~L}^{-1}$. The non-metalcomplexing tertiary amine ("Better") buffer [39] MOPS (3-( $N$-morpholino)propanesulfonic-acid) was used at a concentration of $50 \mathrm{mmol} \mathrm{L}^{-1}$ to maintain the $\mathrm{pH}$ of experimental solutions at $7.4 \pm 0.3$. The ionic strength of the buffer solutions was adjusted to $300 \mathrm{mmol} \mathrm{L}^{-1}$ by addition of $\mathrm{NaCl}$. Solutions in blank treatments contained only pH-buffer and electrolyte, while DFOB (Novartis) treatments additionally contained $1 \mathrm{mmol} \mathrm{L}^{-1}$ DFOB. In $\mathrm{H}_{2} \mathrm{O}_{2}$ decomposition experiments DFOB was used to quench the redox-activity of Fe. This method has been used previously, e.g. in refs [40, 41]. Finally, $\mathrm{H}_{2} \mathrm{O}_{2}$ decomposition was also studied in $0.1 \mathrm{~mol} \mathrm{~L}^{-1}$ $\mathrm{NaOH}$ solutions in which chrysotile fibers are practically insoluble [21].

\section{Preconditioning of chrysotile fibers}

Fibers were preconditioned to obtain fiber types with different specific surface chemistry. The preconditioning involved incubation of the fibers in blank solutions 
buffered at pH 7.4 for $336 \mathrm{~h}$ ("blank-altered fibers") or in $1 \mathrm{mmol} \mathrm{L}^{-1}$ DFOB solutions buffered at $\mathrm{pH} 7.4$ ("DFOBaltered fibers"). In previous studies it was shown that in blank-altered fibers, the outermost Mg layer had dissolved during preconditioning and the Fe content of the dissolved $\mathrm{Mg}$ layer had precipitated as secondary $\mathrm{Fe}$ phases with low Fenton activity [21, 37]. Moreover, in DFOB-altered fibers the Fe content of the dissolved outermost $\mathrm{Mg}$ layer as well as the Fe content of the slowly dissolving Si layer was complexed and mobilized by DFOB. Fe mobilization from the Si layer presumably leads to the formation of vacancy sites, which promote Si dissolution [21]. During preconditioning up to $4 \%$ of the fiber mass dissolved; assuming a cylindrical fiber geometry with constant length, this corresponds with a $2 \%$ decrease in SSA, which is smaller than the standard deviation on the BET-SSA analysis and was considered negligible.

To test whether external Fe can be incorporated into vacancy sites in the $\mathrm{Si}$ layer and whether this incorporated $\mathrm{Fe}$ participates in $\mathrm{H}_{2} \mathrm{O}_{2}$ decomposition and $\mathrm{HO}^{\circ}$ generation, DFOB-altered fibers were suspended in solutions buffered at $\mathrm{pH} 7.4$ containing $0,3,30$ and $300 \mu \mathrm{mol} \mathrm{L}^{-1}$ of $\mathrm{Fe}^{2+}$ under anoxic conditions in a $\mathrm{N}_{2^{-}}$ filled anoxic chamber (Brown box). The suspensions were then immediately oxygenated outside the anoxic chamber by air bubbling for $24 \mathrm{~h}$, while magnetically stirring them at 500 rotations per minute. The $\mathrm{Fe}^{2+}$ rapidly oxidized and $\mathrm{Fe}$ not incorporated into vacancy sites precipitated onto fiber surfaces as $\mathrm{Fe}$ (hydr)oxide minerals, coloring the fibers beige to yellow (see Fig. 1). As a negative control, the same concentrations of Fe were precipitated onto blank-altered fibers (which presumably lack vacancy sites in the Si layer) following the same procedure. The obtained altered fiber types are referred to as "DFOB-altered fibers $+0,3,30$ or $300 \mu \mathrm{mol} \mathrm{g} \mathrm{g}^{-1}$ Fe" and "blank-altered fibers $+0,3,30$ or $300 \mu \mathrm{mol} \mathrm{g}^{-1}$

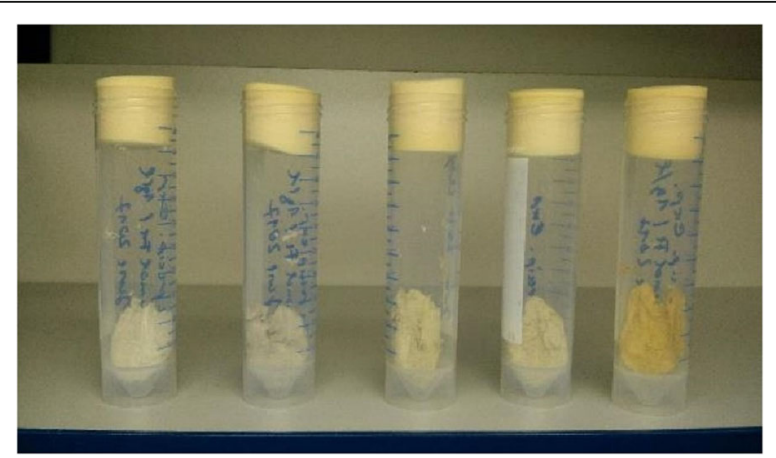

Fig. 1 Preconditioned fibers. From left to right: DFOB-altered fibers with 0,3 and $30 \mu \mathrm{mol} \mathrm{g}^{-1} \mathrm{Fe}$, respectively, blank-altered fibers with $0 \mu \mathrm{mol} \mathrm{g}{ }^{-1} \mathrm{Fe}$ and DFOB-altered fibers with $300 \mu \mathrm{mol} \mathrm{g}^{-1} \mathrm{Fe}$
Fe". Preconditioned fibers were collected in Büchner funnels on $0.47 \mu \mathrm{m}$ Nylon membranes (Magna) and dried by vacuum filtration. To remove potentially adsorbed DFOB ligand or metal-DFOB complexes, fibers were washed with ultra-pure water and then vacuumdried and stored in an evacuated desiccator until they were used in follow-up experiments. Metal and Si concentrations mobilized during the fiber preparations are presented in Additional file 1: Table S1.

\section{${ }^{57} \mathrm{Fe}$ addition and Mössbauer analyses}

${ }^{57} \mathrm{Fe}$ Mössbauer spectroscopy was performed at room temperature in standard constant acceleration mode with a ${ }^{57} \mathrm{CoRh}$ source, relative to which all center shift data are given. The analyzed fiber types were DFOBaltered and blank-altered fibers $+0 \mu \mathrm{mol} \mathrm{g}^{-1} \mathrm{Fe}$, and DFOB-altered and blank-altered fibers $+3 \mu \mathrm{mol} \mathrm{g}^{-1} \mathrm{Fe}$. These fiber types were prepared following the procedure described above, except that isotopically enriched ${ }^{57} \mathrm{Fe}$ (Sigma Aldrich, $>95$ atom \% isotopic purity) was used. The isotopically enriched metallic ${ }^{57} \mathrm{Fe}$-powder was dissolved over night at $70^{\circ} \mathrm{C}$ in a $2 \mathrm{~mol} \mathrm{~L}^{-1} \mathrm{HCl}$ solution, according to Arrigo et al. (2017) [42]. This procedure yielded a ${ }^{57} \mathrm{Fe}^{2+}$ solution, which was purged with $\mathrm{N}_{2}$ for $2 \mathrm{~h}$ and then put into the anoxic glove box. The isotopic composition of Fe in the stock solution was verified by ICP-MS $\left({ }^{57} \mathrm{Fe}\right.$ accounted for $99.2 \%$ of the total $\left.\mathrm{Fe}\right)$, and the $\mathrm{Fe}^{2+}$ concentration was verified spectrophotometrically with a ferrozine assay [43]. Aliquots of the ${ }^{57} \mathrm{Fe}^{2+}$ stock solution were added to DFOB-altered and blankaltered fiber suspensions to obtain an added concentration of $3 \mu \mathrm{mol} \mathrm{g}^{-1}{ }^{57} \mathrm{Fe}^{2+}$.

After vacuum filtration and drying of the fibers, 700 $\mathrm{mg}$ of each fiber type were ground in a tungsten carbide ball mill (Resch Schwingmühle MM 400) for $30 \mathrm{~s}$ (a duration that does not affect $\mathrm{Fe}^{2+} / \mathrm{Fe}^{3+}$ ratios in minerals [44]) at 30 strokes per minute in order to avoid spatial anisotropy of fibers in specimens. $500 \mathrm{mg}$ of the milled fibers were pressed between Teflon foils (Zuma). Mössbauer measurements required up to 2 weeks per samples (Fig. 2). The spectroscopic data were analyzed by solving the full Hamiltonian. Thickness of the samples was taken into account after Mørup and Both (1975) [45]. A ferrihydrite sub-spectrum (based on data from Murad and Schwertmann, 1980, [46]) was used to account for Fe precipitation on blank-altered fibers $+0 \mu \mathrm{molg}^{-1}$ ${ }^{57} \mathrm{Fe}$ (precipitation of $\mathrm{Fe}$ from the dissolved $\mathrm{Mg}$ layer) and DFOB-altered and blank-altered fibers $+3 \mu \mathrm{mol} \mathrm{g}^{-1}$ ${ }^{57} \mathrm{Fe}$ (precipitation of added ${ }^{57} \mathrm{Fe}$ ). Ferrihydrite was selected, because under the experimental conditions such a poorly crystalline $\mathrm{Fe}^{3+}$ (hydr)oxide mineral is most likely to precipitate. Fits involving DFOB-altered fibers $+0 \mu \mathrm{mol} \mathrm{g}{ }^{-1}{ }^{57} \mathrm{Fe}$ were done with and without ferrihydrite sub-spectrum; including the ferrihydrite sub- 


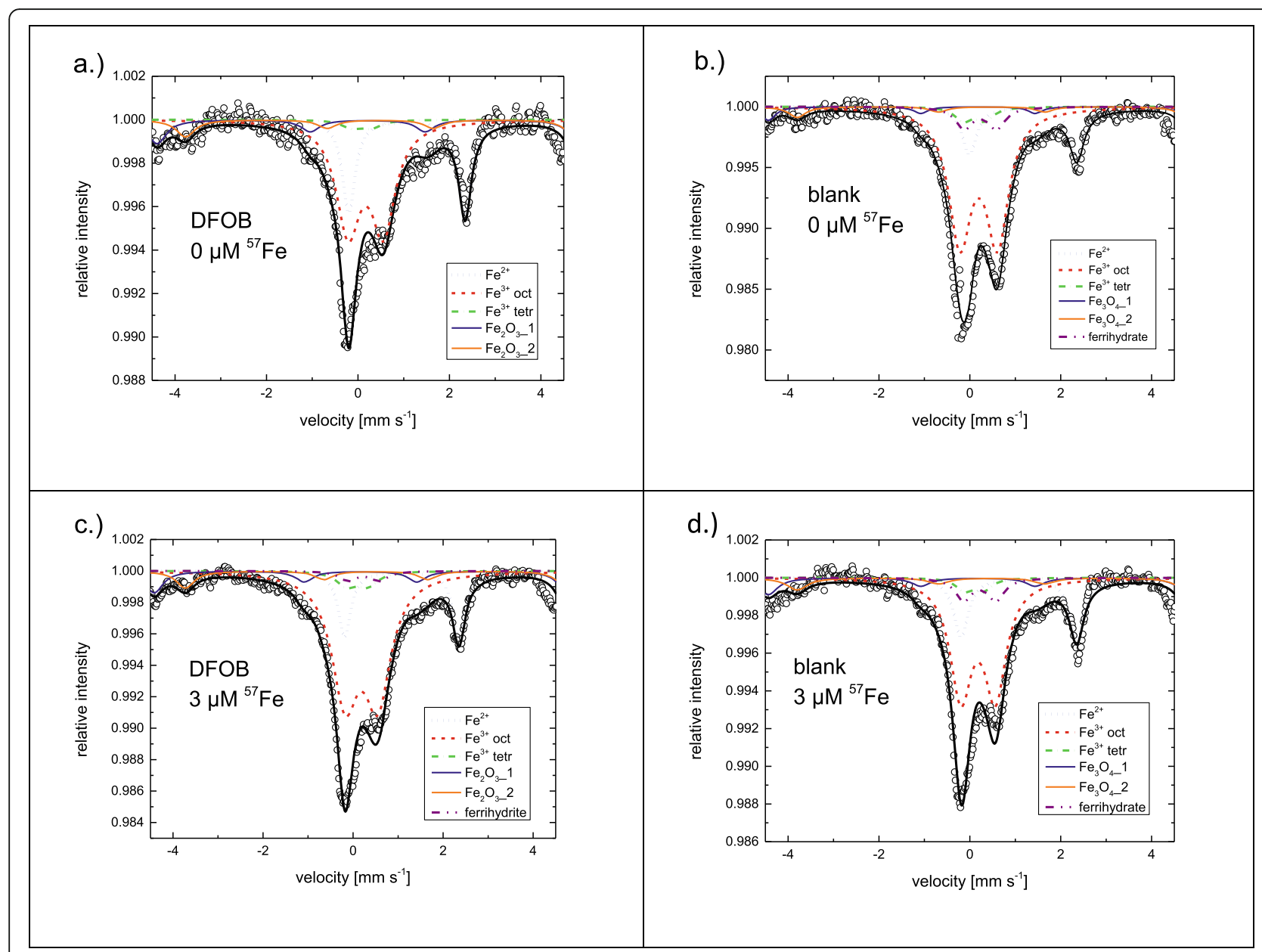

Fig. 2 Narrow velocity range Mössbauer spectra of DFOB-altered fibers (Panel a and c) and blank-altered fibers (Panel b and d) with 0 or $3 \mu$ mol $\mathrm{g}^{-1}$ added ${ }^{57} \mathrm{Fe}$. Spectra for blank-altered fibers and DFOB-altered fibers $+3 \mu \mathrm{mol} \mathrm{g}{ }^{-1}{ }^{57} \mathrm{Fe}$ were fitted with a ferrihydrite sub-spectrum to account for Fe (hydr)oxide precipitation

spectrum did not significantly improve the fit. Because presumably precipitation of ferrihydrite was prevented by addition of DFOB, the fit without the ferrihydrite sub-spectrum was used for comparison with the other treatments. Each sample was measured two times: first in a wider velocity range $\left( \pm 10.6 \mathrm{~mm} \mathrm{~s}^{-1}\right)$ to cover the full magnetically split-spectrum of magnetite impurities, which allowed to obtain the amount of magnetite in the samples, and second in a narrow velocity range $( \pm 4.6$ $\mathrm{mm} \mathrm{s}^{-1}$ ) to better resolve the chrysotile and $\mathrm{Fe}^{3+}$ (hydr)oxide contributions. The obtained hyperfine parameters for both velocity ranges are presented in Additional file 1: Table S2, the spectra of the narrow velocity range are presented in Fig. 2 and the spectra of the wide velocity range in Additional file 1: Figure S1. The magnetite contents were calculated based on the wide velocity range data. After determination of the percentage of magnetite, the percentages of remaining Fe species were determined using the narrow velocity range data by multiplying the narrow velocity range percentages of these Fe species with $(100 \%$ - magnetite\% (wvr)) $/(100 \%$ magnetite\% (nvr)). Finally, all percentages were multiplied by the total amount of ${ }^{57} \mathrm{Fe}$ in each treatment. For blank-altered fibers the Fe content equaled the average content in pristine fibers measured by neutron activation analysis (NAA, Table 1), the amount of Fe removed by DFOB in DFOB-altered fibers was determined from the dissolved Fe concentration after reaction with DFOB. The amount of ${ }^{57} \mathrm{Fe}$ added was known.

\section{Experimental procedure for $\mathrm{H}_{2} \mathrm{O}_{2}$ decomposition experiments}

In the $\mathrm{H}_{2} \mathrm{O}_{2}$ decomposition experiments, metal mobilization from, and decomposition of $\mathrm{H}_{2} \mathrm{O}_{2}$ by, differently preconditioned fibers were assessed. Included fiber types were: pristine fibers, blank-altered fibers, DFOB-altered fibers and both blank-altered and DFOBaltered fibers $+0,3,30$ or $300 \mu^{m o l ~ g}{ }^{-1} \mathrm{Fe}$. Experiments were carried out at pH 7.4 in MOPS buffer, and additionally for pristine and blank-altered fibers in a $0.1 \mathrm{~mol}$ 
$\mathrm{L}^{-1} \mathrm{NaOH}$ solution. The initial experimental $\mathrm{H}_{2} \mathrm{O}_{2}$ concentration was $3.3 \mathrm{~g} \mathrm{~L}^{-1}(\approx 0.3 \%)$, which was prepared by diluting a $30 \%$ stock solution (Sigma Aldrich, for trace analysis) a hundred times. The $\mathrm{H}_{2} \mathrm{O}_{2}$ concentration of the stock was determined by redox titration with $\mathrm{KMnO}_{4}: 334 \pm 2 \mathrm{~g} \mathrm{~L}^{-1} \mathrm{H}_{2} \mathrm{O}_{2}$. Experiments were carried out in duplicates in $15 \mathrm{ml} \mathrm{PP}$ tubes (VWR) that were shaken in an end-over-end shaker at 15 rounds per minutes (RPM) at $20 \pm 2{ }^{\circ} \mathrm{C}$ in the dark. Samples were taken destructively after $0.5,1,4,8,24,48,96,168$ and $336 \mathrm{~h}$. Suspensions were filtered over $0.45 \mu \mathrm{m}$ Sartorius cellulose acetate syringe filters. An aliquot of each filtrate was acidified to $0.14 \mathrm{~mol} \mathrm{~L}^{-1} \mathrm{HNO}_{3}$ (trace metal grade) for metal ( $\mathrm{Mg}$ and $\mathrm{Fe}$ ) and $\mathrm{Si}$ concentration analysis by ICP-OES (Perkin Elmer Optima 5300-DV). Another aliquot of each filtrate was diluted for $\mathrm{H}_{2} \mathrm{O}_{2}$ concentration measurements. Calibration standards for ICP-OES analysis were matrix-matched with the samples. The decomposition of $\mathrm{H}_{2} \mathrm{O}_{2}$ was assessed by measuring the $\mathrm{H}_{2} \mathrm{O}_{2}$ concentration in diluted filtrates immediately after each sampling round. $\mathrm{H}_{2} \mathrm{O}_{2}$ concentrations were determined spectrophotometrically by a titanium sulfate method [47]. One $\mathrm{ml}$ of a $1.9-2.1 \%$ titanium (IV) oxysulfate solution (Sigma Aldrich) was added to $0.5 \mathrm{ml}$ of the diluted filtrate and light absorption by the resulting peroxytitanyl-ion was measured at $410 \mathrm{~nm}$ by a Varian Cary 50 UV/VIS spectrophotometer $\left(\varepsilon=689 \mathrm{~L} \mathrm{~mol}^{-1} \mathrm{~cm}^{-1}\right) . \mathrm{H}_{2} \mathrm{O}_{2}$ concentrations in the samples were quantified by an external linear calibration method (7 to $42 \mathrm{mg} \mathrm{L}^{-1} \mathrm{H}_{2} \mathrm{O}_{2}$ ); filtrates were diluted down to fit the calibration range. Because $\mathrm{H}_{2} \mathrm{O}_{2}$ also reacts with MOPS buffer [48], a control treatment to determine the $\mathrm{H}_{2} \mathrm{O}_{2}$ decomposition rate in absence of fibers was also included. Also for experiments in $0.1 \mathrm{~mol}$ $\mathrm{L}^{-1} \mathrm{NaOH}$ a control treatment without fibers was included. In an additional experiment, $\mathrm{H}_{2} \mathrm{O}_{2}$ decomposition by pristine, blank-altered and DFOB-altered fibers was examined at $\mathrm{pH} 7.4$ in the presence of $1 \mathrm{mmol} \mathrm{L}^{-1}$ DFOB using the same experimental procedure. The absorption maximum of the FeDFOB complex $(425 \mathrm{~nm}$; $\varepsilon=2460 \mathrm{~L} \mathrm{~mol}^{-1} \mathrm{~cm}^{-1}$, [49]) and the peroxytitanyl-ion (vide supra) $[47,50]$ are in close proximity. However, FeDFOB concentrations were orders of magnitude smaller and the molar absorption coefficients of the complexes are less than one order of magnitude different. Therefore, the contribution of FeDFOB to overall light absorption at $410 \mathrm{~nm}$ could be neglected.

EPR spin trapping analyses of hydroxyl radicals generated by $\mathrm{Fe}$ on chrysotile fibers surfaces

The $\mathrm{HO}^{\circ}$ yield of fiber specimens in the presence of $\mathrm{H}_{2} \mathrm{O}_{2}$ was quantified with 5-5-dimethyl-1-pyrroline $\mathrm{N}$-oxide (DMPO) as spin trapping agent using a X-band EPRspectrometer (Bruker EMX) and a split ring resonator
(Bruker MD5). This spin trapping technique has frequently been used for this purpose before $[26,31,37,51$, 52]. Eleven $\mathrm{mg}$ of fibers were incubated for $0.5 \mathrm{~h}$ in $0.5 \mathrm{ml}$ of a $125 \mathrm{mmol} \mathrm{L}^{-1} \mathrm{H}_{2} \mathrm{O}_{2}$ and $12.5 \mathrm{mmol} \mathrm{L}^{-1}$ DMPO solution buffered at pH7.3 with a $250 \mathrm{mmol} \mathrm{L}^{-1}$ chelextreated phosphate buffer. After $25 \mathrm{~min}$ of incubation at room temperature and $5 \mathrm{~min}$ of centrifugation $(14,000$ $\mathrm{RPM}), 50 \mu \mathrm{l}$ of the supernatant were pipetted into a glass capillary (intraMark Blaubrand), which was then sealed with Critoseal. Subsequently, the capillary was transferred into the resonator. The instrumental settings for the EPR measurements are described in Walter et al. (2019) [21]. EPR measurements were performed on four subsamples from each type of preconditioned fibers (quadruplicates). To quantify the change in $\mathrm{HO}^{*}$ yield, the signal intensity (Intensity peak-to-peak (Ipp)) of the second peak from the left in the $\mathrm{DMPO} / \mathrm{HO}^{*}$ quadruplet of altered fibers was determined and expressed as a percentage of the Ipp of pristine fibers, which was measured as a reference in each measurement session. For comparison, also the $\mathrm{HO}^{\circ}$ yield of the poorly crystalline Fe (oxy)hydroxide 2-line ferrihydrite $(3 \pm 0.2 \mathrm{mg}$, synthesized according to Schwertmann and Cornell (2000), [53]) was measured following the same procedure. An amorphous Fe (hydr)oxide like 2-line ferrihydrite may precipitate upon Fe addition to the fibers and subsequent oxygenation [53, 54].

\section{Statistical analysis and supplementary data}

Statistical analysis of the EPR spin trapping data was performed with the program SPSS Version 25. A square root transformation of the data was carried out to reduce skewness. Homogeneity of the transformed data was tested with the Levene's test $(\alpha=0.05)$. Differences among treatments were established by applying the univariate general linear model procedure and the Tukey post-hoc test $(\alpha=0.05)$. A statistical test was employed to answer a) if the $\mathrm{HO}^{\circ}$ yield increased with the amount of Fe applied to DFOB-altered fibers and b) if, through addition of Fe to DFOB-altered fibers, the $\mathrm{HO}^{*}$ yield of blank-altered fibers could be reached.

The data included in Figs. 2, 3, 4 and 5 are reported in Additional file 1: Table S2 to Table S5, respectively. The $p$-values from the statistical analyses of the EPR data are reported in Additional file 1: Table S6.

\section{Results}

\section{Color changes related to $\mathrm{Fe}$ at chrysotile surfaces}

Complexation and mobilization of Fe from the beige pristine chrysotile fibers by DFOB resulted in the whitish color of DFOB-altered fibers (Fig. 1). Interaction of DFOB-altered fibers with $3 \mu \mathrm{molg}^{-1} \mathrm{Fe}$ changed the whitish color to greyish after exposure to oxygen; interaction with $30 \mu \mathrm{mol} \mathrm{g}^{-1} \mathrm{Fe}$ reversed the color to beige, comparable to the color of pristine (not shown) and 

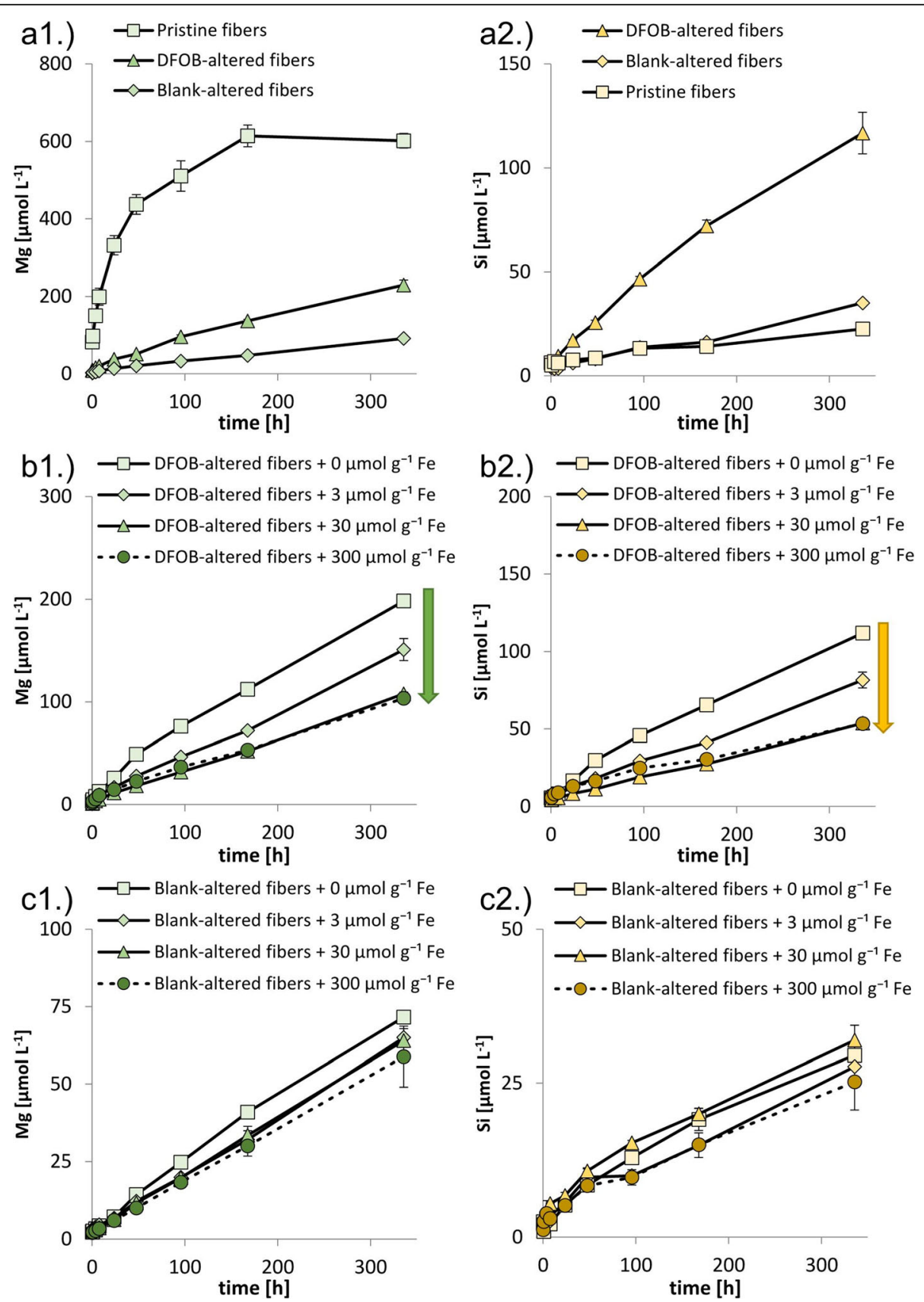

Fig. $3 \mathrm{Mg}$ and Si mobilization from $1 \mathrm{~g} \mathrm{~L}^{-1}$ pristine and preconditioned fibers incubated at $\mathrm{pH} 7.4$ (50 mmol L $\left.\mathrm{L}^{-1} \mathrm{MOPS}\right)$ with addition of $3.34 \mathrm{~g} \mathrm{~L}$ ${ }^{1} \mathrm{H}_{2} \mathrm{O}_{2}$. Panel a.) Mobilized Mg (a1) and $\mathrm{Si}$ (a2) concentrations from pristine, blank-altered and DFOB-altered fibers; Panel b.) Mobilized Mg (b1) and Si (b2) concentrations from DFOB-altered fibers $+0,3,30$ and $300 \mu \mathrm{mol} \mathrm{g}^{-1} \mathrm{Fe}$. The arrows indicate a decrease in mobilized Mg and Si concentration with increasing Fe addition; Panel c.) Mobilized Mg (c1) and Si (c2) concentrations from blank-altered fibers + 0, 3, 30 and $300 \mathrm{mmol} \mathrm{g}^{-1}$ Fe. Error bars indicate standard deviations $(n=2)$

blank-altered fibers, and interaction with $300 \mu \mathrm{mol} \mathrm{g}^{-1}$ Fe changed the color to yellow (Fig. 1). Interaction of pristine fibers with 0,3 and $30 \mu \mathrm{mol} \mathrm{g}^{-1}$ Fe did not lead to a clear change in the beige fiber color of blank-altered fibers, whereas addition of $300 \mu \mathrm{mol} \mathrm{g}^{-1} \mathrm{Fe}$ again changed the color of the fibers to yellow (Additional file 1: Figure S2).

\section{Coordination environment of ${ }^{57} \mathrm{Fe}$ after interaction with chrysotile surfaces}

The contribution of the subspectra to the overall Mössbauer spectrum differed per fiber type (Fig. 2; Additional file 1: Table S2), indicating that preconditioning induced a shift in ${ }^{57} \mathrm{Fe}$ species distribution. Preconditioning with DFOB reduced the fraction of Fe present as $\mathrm{Fe}^{3+}{ }_{\text {tet }}$ in 

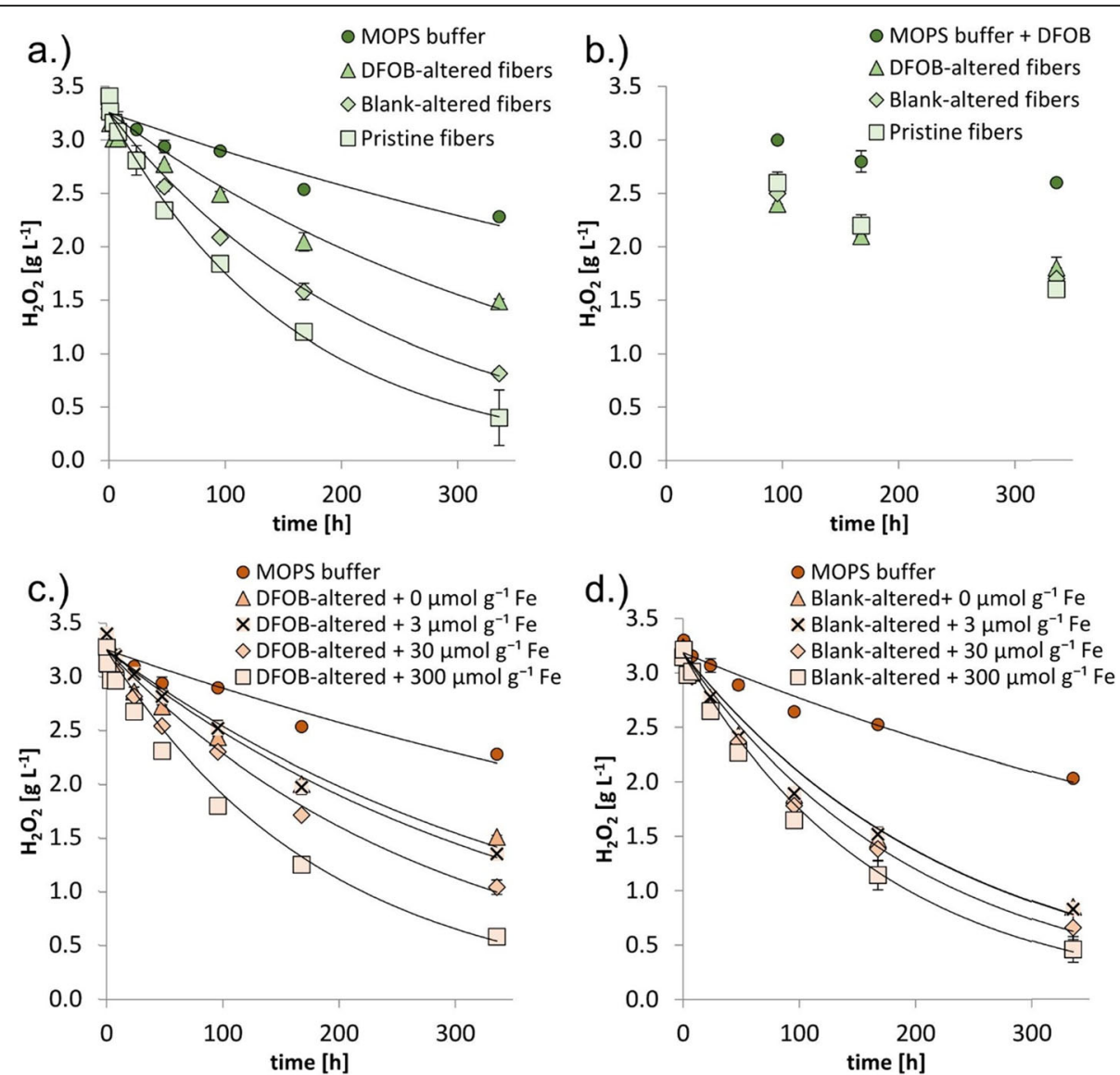

Fig. 4 Decomposition of $\mathrm{H}_{2} \mathrm{O}_{2}$ (initial concentration $3.34 \mathrm{~g} \mathrm{~L}^{-1}$ ) by $1 \mathrm{~g} \mathrm{~L}^{-1}$ pristine and preconditioned chrysotile fibers at $\mathrm{pH} 7.4\left(50 \mathrm{mmol} \mathrm{L}^{-1}\right.$ MOPS). Parameters of the exponential fits of the $\mathrm{H}_{2} \mathrm{O}_{2}$ concentration data are presented in Table 2. Panel a.) Decomposition of $\mathrm{H}_{2} \mathrm{O}_{2}$ in the presence of pristine, blank-altered and DFOB-altered fibers; Panel b.) $\mathrm{H}_{2} \mathrm{O}_{2}$ decomposition in the presence of MOPS buffer +1 mmol $\mathrm{L}^{-1}$ DFOB, in absence of fibers, and in presence of pristine, blank-altered and DFOB-altered fibers; Panel c-d.) Decomposition of $\mathrm{H}_{2} \mathrm{O}_{2}$ in absence of fibers and in presence of DFOB-altered fibers $+0,3,30$ and $300 \mu_{\text {mol g }}^{-1}$ Fe (Panel c) and blank-altered fibers $+0,3,30$ and $300 \mu \mathrm{mol} \mathrm{g}{ }^{-1} \mathrm{Fe}$ (Panel d). Error bars indicate standard deviations $(n=2)$

comparison to the blank-altered treatment (Fig. 2 panel a an b; Additional file 1: Table S2c) and lowered the $\mathrm{Fe}^{3+}{ }_{\text {tet }}$ content by half, from 15.0 to $7.7 \mu \mathrm{mol} \mathrm{g}^{-1} \mathrm{Fe}$ (Additional file 1: Table S7). As only $4 \%$ of the fiber mass had dissolved during preconditioning, this suggests that $\mathrm{Fe}^{3+}$ tet sites are not homogenously distributed over the chrysotile bulk, but are strongly enriched in Si layers near the fiber surface. Addition of $3 \mu \mathrm{mol}$ of ${ }^{57} \mathrm{Fe}$ per gram of DFOB-altered fibers increased the ${ }^{57} \mathrm{Fe}^{3+}$ tet fraction (Fig. 2 panel a and c) from 2.2 to $3.8 \%$ (Additional file 1: Table S2c). This corresponds with an increase in total $\mathrm{Fe}^{3+}{ }_{\text {tet }}$ bulk content by 3\% (Additional file 1: Table S7), suggesting a marginal recovery of $\mathrm{Fe}^{3+}{ }_{\text {tet }}$ sites at chrysotile surfaces by addition of ${ }^{57} \mathrm{Fe}$. Most added ${ }^{57} \mathrm{Fe}$ $\left(1.8 \mu \mathrm{mol} \mathrm{g}{ }^{-1} \mathrm{Fe} \approx 60 \%\right)$ was retrieved as $\mathrm{Fe}^{3+}$ oct. In contrast, addition of $3 \mu \mathrm{mol}$ of ${ }^{57} \mathrm{Fe}$ per gram of blankaltered fibers resulted in a decrease in ${ }^{57} \mathrm{Fe}^{3+}$ tet fraction (Fig. 2 panel $b$ and d) from 4.0 to $3.3 \%$ (Additional file 1: Table S2c) and a negligible change (0.3\%) in total $\mathrm{Fe}^{3+}{ }_{\text {tet }}$ bulk content $\left(14.9 \mu \mathrm{mol} \mathrm{g}^{-1} \mathrm{Fe}\right.$, Additional file 1: Table S7). Most added ${ }^{57} \mathrm{Fe}\left(1.8 \mu \mathrm{mol} \mathrm{g}^{-1} \mathrm{Fe} \approx 60 \%\right)$ was retrieved as magnetite.

\section{Dissolution of metals and Si from pristine and preconditioned chrysotile fibers in the presence of $\mathrm{H}_{2} \mathrm{O}_{2}$} In Fig. 3, $\mathrm{Mg}$ and $\mathrm{Si}$ concentrations mobilized from pristine and preconditioned chrysotile fibers in the presence of $\mathrm{H}_{2} \mathrm{O}_{2}$ (initial concentration: $3.34 \mathrm{~g} \mathrm{~L}^{-1}$ ) are reported as a function of time. Fe concentrations were in the submicromolar range throughout all these experiments (data no shown). In contrast to our results, Ghio et al. (1998) reported somewhat higher mobilized Fe concentrations from a different chrysotile preparation by $\mathrm{H}_{2} \mathrm{O}_{2}$ [32].

For $\mathrm{Mg}$ mobilization from pristine chrysotile fibers, two stages could be distinguished (Fig. 3, Panel a1): a fast first stage during which the outermost $\mathrm{Mg}$ layer of the fibers rapidly dissolved (first few days), and a slower 

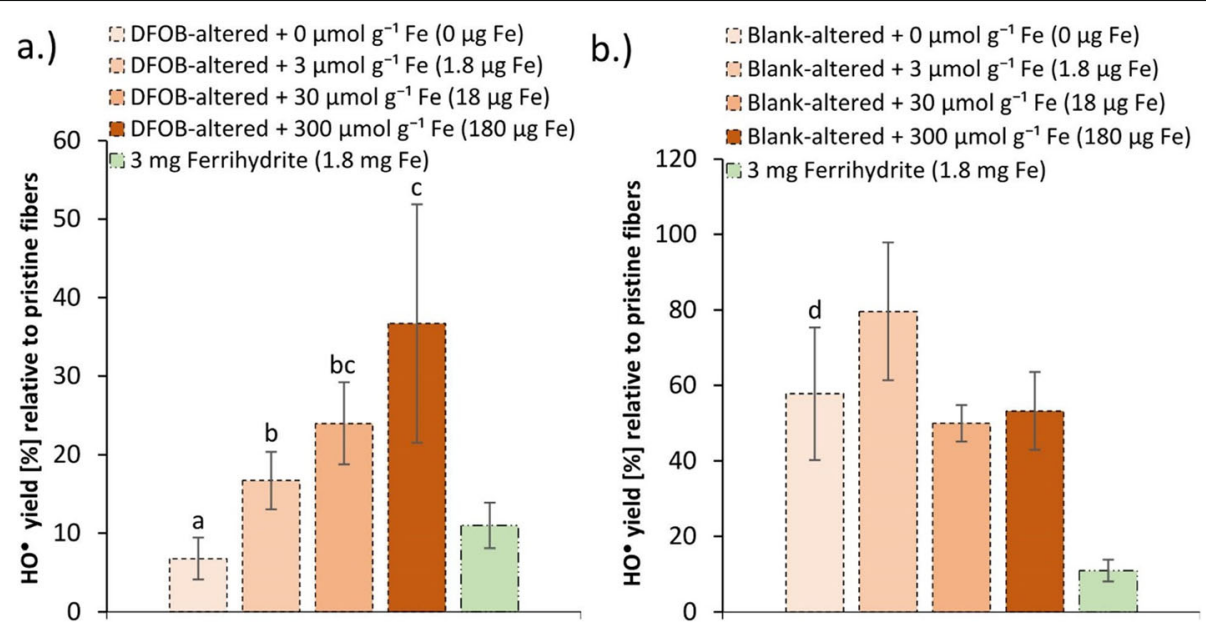

Fig. $5 \mathrm{HO}^{*}$ yield of preconditioned fibers and ferrithydrite measured by the DMPO/HO-EPR signal intensity. The signal is expressed as a precentage of the $\mathrm{HO}^{\circ}$ yield of pristine fibers, which was analyzed at every measuring session as a reference. Panel a.) $\mathrm{HO}^{*}$ yield of DFOB-altered fibers $+0,3,30$ and $300 \mu \mathrm{mol} \mathrm{g}{ }^{-1} \mathrm{Fe}$, and $3 \mathrm{mg}$ ferrihydrite; Panel b.) HO yield of blank-altered fibers $+0,3,30$ and $300 \mu \mathrm{mol} \mathrm{g}{ }^{-1} \mathrm{Fe}$ and 3 mg ferrihydrite. The letters indicate significantly different $\mathrm{HO}^{\circ}$ yields as identified by the Tukey post-hoc test following an ANOVA. The results illustrate an increase in $\mathrm{HO}^{\circ}$ yield upon addition of Fe to DFOB-altered fibers, yet the $\mathrm{HO}^{*}$ yield of blank-altered fibers was not reached. Error bars indicate standard deviations $(n=4)$

second stage during which the outermost $\mathrm{Mg}$ layer had been completely dissolved, Si dissolution had become rate limiting and mobilized $\mathrm{Mg}$ concentrations reached a plateau at approximately 500 to $600 \mu \mathrm{mol} \mathrm{L}^{-1}$ (between 96 and $336 \mathrm{~h}$ ). Mg mobilization from DFOB-altered and blank-altered fibers could not be divided into two dissolution stages, but increased linearly throughout the experiment. Si concentrations mobilized from all three fiber types increased linearly throughout the experiment (Fig. 3, Panel a2). Mobilized Si concentrations were consistently higher for DFOB-altered fibers than for blankaltered and pristine fibers. Adsorption and precipitation of added Fe onto DFOB-altered fiber surfaces decreased the rate of Mg (Fig. 3, Panel b1) and Si (Fig. 3, Panel b2) mobilization throughout the experiment. The decrease in $\mathrm{Mg}$ and $\mathrm{Si}$ dissolution rates were however not proportional to the amount of Fe applied and reached a maximum of approximately $50 \%$ with addition of $30 \mu \mathrm{mol} \mathrm{g}^{-}$ ${ }^{1} \mathrm{Fe}$. Adsorption and precipitation of added $\mathrm{Fe}$ onto blank-altered fiber surfaces did not decrease $\mathrm{Mg}$ and $\mathrm{Si}$ mobilization as strongly as for DFOB-altered fibers (Fig. 3, Panel $\mathrm{c} 1$ and c2, respectively): addition of $300 \mu \mathrm{mol} \mathrm{g}^{-}$

1 Fe only decreased mobilized $\mathrm{Mg}$ concentrations by $18 \%$ and mobilized Si concentrations by $20 \%$ after $336 \mathrm{~h}$.

\section{$\mathrm{H}_{2} \mathrm{O}_{2}$ decomposition by pristine and preconditioned chrysotile fibers}

$\mathrm{H}_{2} \mathrm{O}_{2}$ decomposition kinetics in the presence of chrysotile and MOPS buffer could be well described with a first order rate equation in $\mathrm{H}_{2} \mathrm{O}_{2}$ concentration:

$$
\operatorname{Rate}_{\left(\mathrm{H}_{2} \mathrm{O}_{2}\right)}=-\frac{d\left[\mathrm{H}_{2} \mathrm{O}_{2}\right]}{d t}=k_{t o t}\left[\mathrm{H}_{2} \mathrm{O}_{2}\right]
$$

in which $\mathrm{k}_{\text {tot }}$ is the overall decomposition constant. Chrysotile fibers accelerated $\mathrm{H}_{2} \mathrm{O}_{2}$ decomposition relative to the MOPS-buffer control treatment by a factor 2 to 5 , depending on the pretreatment (Fig. 4a, Table 2). $\mathrm{H}_{2} \mathrm{O}_{2}$ decomposition was fastest with pristine fibers and slowest with DFOB-altered fibers. The addition of DFOB as a redox quencher for Fe largely inhibited differences in the $\mathrm{H}_{2} \mathrm{O}_{2}$ decomposition rate between pristine, blank-altered and DFOB-altered fibers (Fig. 4b). In the treatment with DFOB-altered fibers, the application of DFOB as redox quencher had no effect on $\mathrm{H}_{2} \mathrm{O}_{2}$ decomposition; for the treatments with pristine and blank-altered fibers, $\mathrm{H}_{2} \mathrm{O}_{2}$ decomposition decreased as a result of DFOB addition (Fig. $4 \mathrm{a}$ and $\mathrm{b}$ ). For the treatments with DFOB-altered fibers and DFOB-altered fibers $+0 \mu \mathrm{mol} \mathrm{g}^{-1} \mathrm{Fe}, \mathrm{k}_{\text {tot }}$ values did not differ $\left(2.5^{*} 10^{-3} \mathrm{~h}^{-1}\right)$, demonstrating that the fiber preparation procedure without $\mathrm{Fe}$ addition did not affect the $\mathrm{H}_{2} \mathrm{O}_{2}$ decomposition rate. Fe addition to DFOBaltered fibers increased $\mathrm{k}_{\text {tot }}$ values by up to over a factor 2 in the DFOB-altered fibers $+300 \mu \mathrm{mol} \mathrm{g}^{-1} \mathrm{Fe}\left(5.3^{*} 10^{-3}\right.$ $\mathrm{h}^{-1}$ ); the increase in $\mathrm{k}_{\text {tot }}$ was non-proportional to the amount of Fe added (Fig. 4c, Table 2). A non-proportional increase in $\mathrm{k}_{\text {tot }}$ values was also found for treatments in which Fe had been added to blank-altered fibers. The relative increase was however smaller, amounting a factor 1.4 (from $4.2 * 10^{-3} \mathrm{~h}^{-1}$ to $6.0^{*} 10^{-3} \mathrm{~h}^{-1}$; Fig. $4 \mathrm{~d}$, Table 2).

The contributions from different reactive sites on chrysotile surfaces to overall $\mathrm{H}_{2} \mathrm{O}_{2}$ decomposition can be estimated in a tiered approach (Table 3 ), under the assumption that the various degradation mechanisms are independent, and their decomposition constants add up to the $\mathrm{k}_{\text {tot }}$ of the reaction. Equation 1 can then be rewritten to equation 2 : 
Table $2 \mathrm{H}_{2} \mathrm{O}_{2}$ decomposition rate constants ( $\left.\mathrm{k}_{\text {tot }}\right)$ and corresponding half-life times determined by fitting the $\mathrm{H}_{2} \mathrm{O}_{2}$ concentration data presented in Fig. 4 to the first order rate equation: Rate $_{\left(\mathrm{H}_{2} \mathrm{O}_{2}\right)}=-\frac{d\left[\mathrm{H}_{2} \mathrm{O}_{2}\right]}{d t}=k_{\text {tot }}\left[\mathrm{H}_{2} \mathrm{O}_{2}\right]$

\begin{tabular}{|c|c|c|c|c|}
\hline Experiment $\mathrm{Nr}$. & Treatment & First order rate constant $\mathrm{k}_{\text {tot }}\left[\mathrm{h}^{-1}\right]$ & $R^{2}$ & $\overline{\mathrm{t}_{1 / 2}[\mathrm{~h}]}$ \\
\hline 1 & MOPS pristine fibers & $6.2^{*} 10^{-3}$ & 0.998 & 112 \\
\hline 2 & MOPS blank-altered fibers & $4.2^{*} 10^{-3}$ & 0.996 & 165 \\
\hline 3 & MOPS DFOB-altered fibers & $2.5^{*} 10^{-3}$ & 0.956 & 277 \\
\hline 4 & MOPS DFOB-altered fibers $+0 \mu \mathrm{mol} \mathrm{g}{ }^{-1} \mathrm{Fe}$ & $2.5^{*} 10^{-3}$ & 0.944 & 277 \\
\hline 5 & MOPS DFOB-altered fibers $+3 \mu \mathrm{mol} \mathrm{g}{ }^{-1} \mathrm{Fe}$ & $2.7^{*} 10^{-3}$ & 0.992 & 257 \\
\hline 6 & MOPS DFOB-altered fibers $+30 \mu \mathrm{mol} \mathrm{g}^{-1} \mathrm{Fe}$ & $3.5^{*} 10^{-3}$ & 0.982 & 198 \\
\hline 7 & MOPS DFOB-altered fibers $+300 \mu \mathrm{mol} \mathrm{g}^{-1} \mathrm{Fe}$ & $5.3^{*} 10^{-3}$ & 0.986 & 131 \\
\hline 8 & MOPS buffer (no fibers) panel a \& c of Fig. 4 & $1.2^{*} 10^{-3}$ & 0.931 & 578 \\
\hline 9 & MOPS blank-altered fibers $+0 \mu \mathrm{mol} \mathrm{g}^{-1} \mathrm{Fe}$ & $4.2^{*} 10^{-3}$ & 0.979 & 165 \\
\hline 10 & MOPS blank-altered fibers $+3 \mu \mathrm{mol} \mathrm{g}^{-1} \mathrm{Fe}$ & $4.2^{*} 10^{-3}$ & 0.983 & 165 \\
\hline 11 & MOPS blank-altered fibers $+30 \mu \mathrm{mol} \mathrm{g}^{-1} \mathrm{Fe}$ & $4.9^{*} 10^{-3}$ & 0.988 & 142 \\
\hline 12 & MOPS blank-altered fibers $+300 \mu \mathrm{mol} \mathrm{g}{ }^{-1} \mathrm{Fe}$ & $6.0^{*} 10^{-3}$ & 0.995 & 116 \\
\hline 13 & MOPS buffer (no fibers) panel d of Fig. 4 & $1.4^{*} 10^{-3}$ & 0.995 & 495 \\
\hline 14 & $\mathrm{NaOH}$ pristine fibers & $46.7^{*} 10^{-3}$ & 0.936 & 14.8 \\
\hline 15 & $\mathrm{NaOH}$ blank-altered fibers & $41.5^{*} 10^{-3}$ & 0.995 & 16.7 \\
\hline 16 & $\mathrm{NaOH}$ (no fibers) & $1.0^{*} 10^{-3}$ & 0.772 & 693 \\
\hline
\end{tabular}

$$
\operatorname{Rate}_{\left(\mathrm{H}_{2} \mathrm{O}_{2}\right)}=-\frac{d\left[\mathrm{H}_{2} \mathrm{O}_{2}\right]}{d t}=\left(k_{1}+\ldots+k_{n}\right)\left[\mathrm{H}_{2} \mathrm{O}_{2}\right]
$$

in which $k_{1}$ to $n$ represent the contributions of the individual $\mathrm{H}_{2} \mathrm{O}_{2}$ decomposition pathways to the overall decomposition constant $\mathrm{k}_{\text {tot }}$. In addition to contributions from tetrahedral $\mathrm{Fe}$ and $\mathrm{Fe}$ (hydr)oxide precipitates, the difference in decomposition rate between the MOPS buffer control and the DFOB-altered fiber treatment suggests a contribution from a remnant $\mathrm{H}_{2} \mathrm{O}_{2}$ decomposition pathway (Fig. 4b, Table 3). The control treatment with MOPS buffer-only provided the contribution from the MOPS buffer to $\mathrm{H}_{2} \mathrm{O}_{2}$ degradation. The contribution from the remnant decomposition pathway was calculated by subtracting the contribution from the MOPS buffer from the $k_{\text {tot }}$ value of the DFOB-altered fiber treatment, under the assumption that DFOB had removed most Fe from the fiber surfaces. For the contribution from $\mathrm{Fe}$ (hydr)oxide precipitates to $\mathrm{H}_{2} \mathrm{O}_{2}$ degradation it was assumed that the outer $\mathrm{Mg}$ and $\mathrm{Si}$ layer contained approximately $30 \mu \mathrm{mol} \mathrm{g}{ }^{-1} \mathrm{Fe}$ (Additional file 1: Table S1, Walter et al. (2019), [21]), that this Fe largely precipitated in the blank treatment as only a small fraction of the Fe is located in the slowly dissolving Si layer (Table 1), and that precipitation of an additional $30 \mu \mathrm{mol} \mathrm{g}{ }^{-1} \mathrm{Fe}$ had the same effect size on the $\mathrm{k}_{\text {tot }}$ value as the Fe that precipitated from the outer layer. The contribution of $\mathrm{Fe}$ (hydr)oxide precipitates to the $\mathrm{k}_{\mathrm{tot}}$ value can then be calculated by subtracting the $k_{\text {tot }}$ value of the blank-altered treatment from the blank-altered + $30 \mu \mathrm{mol} \mathrm{g}^{-1}$ Fe treatment. Finally, the contribution from tetrahedral $\mathrm{Fe}$ was calculated by subtracting the contributions from the MOPS buffer, Fe (hydr)oxide precipitates and the $\mathrm{H}_{2} \mathrm{O}_{2}$ decomposition pathway from the $\mathrm{k}_{\text {tot }}$ value of the blank treatment (Table 3).

Following this approach, the $\mathrm{k}_{\text {tot }}$ value of the blankaltered fiber treatment $\left(4.2 * 10^{-3} \mathrm{~h}^{-1}\right.$; Table 2 , treatment 2) was broken down to contributions from the three types of active surface sites and the MOPS buffer (equation 2). The contributions of the active surface sites to

Table 3 Contributions from different reactive surface sites and the MOPS buffer to the overall $\mathrm{H}_{2} \mathrm{O}_{2}$ decomposition rate constant $\left(k_{\text {tot }}\right)$ for the blank-altered fiber treatment. The fitted constants ( $($ Exp.x)) for the treatments reported in Table 2 were used and linear additivity was assumed

\begin{tabular}{|c|c|c|c|}
\hline Decomposition mode & Experiment $\mathrm{Nr}$. & $\begin{array}{l}\text { Determination of the contribution to } \\
\mathrm{k}_{\text {tot }} \text { of blank- altered fibers }\end{array}$ & $k$-value $\left[h^{-1}\right]$ \\
\hline 1.) MOPS buffer & 8 & $\mathrm{k}(\operatorname{Exp} .8)=\mathrm{k} 1$ & $\mathrm{k} 1=1.2^{*} 10^{-3}$ \\
\hline 2.) Remnant $\mathrm{H}_{2} \mathrm{O}_{2}$ decomposition & 3 & $k(\operatorname{Exp} .3)-k 1=k 2$ & $\mathrm{k} 2=1.3^{*} 10^{-3}$ \\
\hline 3.) Secondary Fe precipitates & 11,9 & $k(\operatorname{Exp} .11)-k(\operatorname{Exp} .9)=k 3$ & $\mathrm{k} 3=0.7^{*} 10^{-3}$ \\
\hline 4.) Tetrahedral Fe & 2 & $\begin{array}{l}\mathrm{k} 1+\mathrm{k} 2+\mathrm{k} 3+\mathrm{k} 4=\mathrm{k}(\operatorname{Exp} .2)=> \\
\mathrm{k}(\operatorname{Exp} .2)-\mathrm{k} 1-\mathrm{k} 2-\mathrm{k} 3=\mathrm{k} 4\end{array}$ & $\mathrm{k} 4=1.0^{*} 10^{-3}$ \\
\hline
\end{tabular}


$\mathrm{k}_{\text {tot }}$ were comparable, varying within a factor 2 , and also the contribution from the MOPS buffer fell within this range (Table 3).

The solution $\mathrm{pH}$ had a strong effect on the $\mathrm{H}_{2} \mathrm{O}_{2}$ decomposition rate: in $0.1 \mathrm{~mol} \mathrm{~L}^{-1} \mathrm{NaOH}(\mathrm{pH} 12-13)$ the decomposition rate by pristine and preconditioned fibers was approximately an order of magnitude faster than at pH 7.4 (Table 2).

\section{Effect of Fe addition to preconditioned chrysotile fibers on $\mathrm{HO}^{\circ}$ generation}

Pretreatment of Shijiazhuang chrysotile asbestos decreased the $\mathrm{HO}^{\circ}$ yield relative to pristine fibers to $50 \pm$ $10 \%$ for blank-altered fibers and to $9 \%$ for DFOB-altered fibers [21]. The $\mathrm{HO}^{*}$ yield of blank-altered and DFOBaltered fibers $+0 \mu \mathrm{mol} \mathrm{g}^{-1} \mathrm{Fe}$ (Fig. 5) corresponded with these values. For all treatments with $\mathrm{Fe}$ addition to DFOB-altered fibers, the $\mathrm{HO}^{*}$ yield was larger than for the $+0 \mu \mathrm{mol} \mathrm{g}^{-1} \mathrm{Fe}$ treatment. The $\mathrm{HO}^{\bullet}$ yield increased non-proportionally with the amount of $\mathrm{Fe}$ added, from $7 \%\left(+0 \mu \mathrm{mol} \mathrm{g}^{-1} \mathrm{Fe}\right)$ to $36 \%\left(+300 \mu \mathrm{mol} \mathrm{g}^{-1} \mathrm{Fe}\right)$ (Fig. 5a; Additional file 1: Table S5). Although a factor 10 more $\mathrm{Fe}$ had been added in the DFOB-altered + $300 \mu \mathrm{mol} \mathrm{g}^{-1} \mathrm{Fe}$ treatment than was extracted in the DFOB-pretreatment, the $\mathrm{HO}^{*}$ yield remained lower than in the blank-altered $+0 \mu \mathrm{mol} \mathrm{g}^{-1} \mathrm{Fe}$ fiber treatment (Fig. 5; Additional file 1: Table S5), suggesting that the $\mathrm{HO}^{\circ}$ yield could be largely, but not fully recovered. The addition of $\mathrm{Fe}$ to blank-altered fibers did not consistently increase the $\mathrm{HO}^{*}$ yield of chrysotile (Fig. 5b). Furthermore, the $\mathrm{HO}^{*}$ yield of $3 \mathrm{mg}$ of 2-line ferrihydrite was $11 \%$ (relative to the $\mathrm{HO}^{*}$ yield of $11 \mathrm{mg}$ pristine chrysotile fibers). The total amount of Fe in $3 \mathrm{mg}$ of 2-line ferrihydrite $(\approx 1.8 \mathrm{mg} \mathrm{Fe})$ is a thousand times larger than the $1.8 \mu \mathrm{g} \mathrm{Fe}$ on the fiber surface of the aliquots of DFOB-altered fibers $+3 \mu \mathrm{mol} \mathrm{g}^{-1} \mathrm{Fe}$. Despite this large difference, the increase in $\mathrm{HO}^{\circ}$ yield (an increase from 7 to $17 \%$ ) due to the $3 \mu \mathrm{mol} \mathrm{g}^{-1}$ Fe addition was comparable with the overall $\mathrm{HO}^{*}$ yield of $3 \mathrm{mg}$ of ferrihydrite (11\%).

\section{Discussion}

\section{Speciation of added $\mathrm{Fe}$ and implications for fiber dissolution}

Si dissolution from DFOB-altered fibers was over a factor three faster than from pristine fibers, whereas Si dissolution from blank-altered and pristine fibers were comparably fast (Fig. 3, Panel a2). The faster Si mobilization from DFOB-altered fibers is a consequence of the complexation of $\mathrm{Fe}^{3+}$ tet by DFOB during pretreatment. Presumably this led to the formation of vacancy sites in the Si layer resulting in Si labilization which enhanced Si dissolution rates [21]. Si mobilization from blank-altered fibers was considerably slower, because no
$\mathrm{Fe}^{3+}$ tet had been removed from the Si layers during pretreatment. The larger Mg mobilization rate from DFOBaltered fibers compared to blank-altered fibers presumably resulted from the larger rate-controlling $\mathrm{Si}$ mobilization rate, allowing segments of deeper Mg layers to dissolve more rapidly; in both treatments the outer Mg layer had been dissolved during pretreatment.

Mössbauer spectroscopy analyses of DFOB-altered and blank-altered fibers $+3 \mu \mathrm{mol} \mathrm{g}^{-1}{ }^{57} \mathrm{Fe}$ demonstrated that the absolute increase in tetrahedrally coordinated ${ }^{57} \mathrm{Fe}$ content was more than 5 times larger when added to DFOB-altered fibers compared to blank-altered fibers (Additional file 1: Table S7). However, assuming that no isotope exchange occurred, the data imply that only a small fraction of the $\mathrm{Fe}^{3+}$ tet sites depleted by DFOB were recovered by ${ }^{57} \mathrm{Fe}$ additions.

Despite the apparently low recovery of depleted vacancy sites as observed by Mössbauer spectroscopy, the interaction of Fe with DFOB-altered fibers re-stabilized the labilized Si layer, reduced the Si dissolution rate, and consequently also reduced the $\mathrm{Mg}$ dissolution rate (Fig. 3 , panel b1 and b2). The 25\% reduction in $\mathrm{Si}$ and $\mathrm{Mg}$ dissolution rate by addition of only $3 \mu \mathrm{mol} \mathrm{g}^{-1} \mathrm{Fe}$ and the fact that $\mathrm{Fe}$ addition beyond $30 \mu \mathrm{mol} \mathrm{g}^{-1}$ did not lead to a further decrease in dissolution rates, supports that the effect of $\mathrm{Fe}$ addition originates from the stabilization of the Si layer rather than from surface coverage by precipitated Fe (hydr)oxide minerals that prevent dissolution. The latter observation also suggests that between addition of 3 and $30 \mu \mathrm{mol} \mathrm{g}^{-1} \mathrm{Fe}$, all vacancy sites became occupied with tetrahedrally coordinated $\mathrm{Fe}$ and further $\mathrm{Fe}$ addition did not affect dissolution rates. The absence of similar trends in $\mathrm{Si}$ and $\mathrm{Mg}$ dissolution for $\mathrm{Fe}$ addition to blank-altered fibers further indicates that external $\mathrm{Fe}$ only becomes tetrahedrally coordinated if there are vacancy sites present in the surface Si layer (Fig. 3, Panel c1 and c2).

\section{Active sites of $\mathrm{H}_{2} \mathrm{O}_{2}$ decomposition on chrysotile surfaces} At pH 7.4, the $\mathrm{H}_{2} \mathrm{O}_{2}$ decomposition rate (Fig. 4a) (as well as the $\mathrm{HO}^{\circ}$ yield (Fig. 5)) was highest in the treatment with pristine fibers. This is presumably related to a (transient) contribution from $\mathrm{Fe}$ in the outermost $\mathrm{Mg}$ layer, which dissolves within a few days at this $\mathrm{pH}$. In the treatment with $\mathrm{NaOH}$ the $\mathrm{Mg}$ layer did not dissolve at all (Additional file 1: Table S8) and the lasting contribution from $\mathrm{Fe}$ in this layer may in part explain the higher $\mathrm{H}_{2} \mathrm{O}_{2}$ decomposition rate.

In addition to two Fe-related modes of $\mathrm{H}_{2} \mathrm{O}_{2}$ decomposition by chrysotile, a third, remnant mode was identified (Fig. 4a and b), which, to our knowledge, had not yet been described for asbestos. It made the largest contribution to the $\mathrm{k}_{\mathrm{tot}}$ of blank-altered fibers in our experiments (Table 3) and may also be relevant in vivo. 
Magnetite impurities in the Shijiazhuang chrysotile that do not dissolve during the DFOB pretreatment may contribute to the remnant $\mathrm{H}_{2} \mathrm{O}_{2}$ decomposition mode. $\mathrm{H}_{2} \mathrm{O}_{2}$ is more rapidly decomposed by magnetite than by asbestos per unit of mass [31], but magnetite is only a phase contaminant in Shijiazhuang chrysotile asbestos $(1.5 \pm 0.2 \%)$, whereas chrysotile is the predominant phase $(86.4 \pm 4.6 \%)$ [21]. Therefore, we assume that the contribution of magnetite to $\mathrm{H}_{2} \mathrm{O}_{2}$ decomposition rates is small. Furthermore, other substituted metal ions (e.g. Cr, $\mathrm{Mn}, \mathrm{Ni}$ ) that are not or only slowly mobilized by DFOB might have contributed to the remnant $\mathrm{H}_{2} \mathrm{O}_{2}$ decomposition mode. And finally, the contribution from small amounts of remnant Fe that were either not mobilized by DFOB during the pretreatment or that became exposed during the $\mathrm{H}_{2} \mathrm{O}_{2}$ decomposition experiments as a result of $\mathrm{Mg}$ and $\mathrm{Si}$ dissolution is counted towards the remnant decomposition mode.

In spite of the smaller surface concentration of $\mathrm{Fe}^{3+}$ tet in blank-altered fibers relative to octahedral $\mathrm{Fe}$ which had precipitated as Fe (hydr)oxide minerals, their contributions to $\mathrm{H}_{2} \mathrm{O}_{2}$ decomposition were comparable (Table 3 ). Several factors may contribute to the comparatively large contribution of $\mathrm{Fe}^{3+}$ tet per mole Fe. First, only a fraction of the $\mathrm{Fe}$ in $\mathrm{Fe}$ precipitates resides at the mineral surface and is able to react with $\mathrm{H}_{2} \mathrm{O}_{2}$, whereas all tetrahedral $\mathrm{Fe}$ substituted into the exposed $\mathrm{Si}$ layer can contribute to $\mathrm{H}_{2} \mathrm{O}_{2}$ decomposition. Secondly, in other silicate minerals like nontronites, it has been shown that $\mathrm{Fe}^{3+}{ }_{\text {tet }}$ is preferentially reduced over octahedral Fe [5557] suggesting a lower redox potential of $\mathrm{Fe}^{3+}{ }_{\text {tet }}$ in silicate minerals. This lower redox potential may contribute to a higher reactivity of $\mathrm{Fe}^{3+}$ tet with regard to $\mathrm{H}_{2} \mathrm{O}_{2}$ decomposition. Also for $\mathrm{Fe}$ (hydr)oxide minerals, it has been demonstrated that for equal masses the $\mathrm{H}_{2} \mathrm{O}_{2}$ decomposition rates were larger for minerals containing $\mathrm{Fe}^{3+}$ tet, like magnetite (even higher than chrysotile), than for minerals that do not contain $\mathrm{Fe}^{3+}$ tet, like hematite [31].

Similarly to $\mathrm{H}_{2} \mathrm{O}_{2}$ decomposition, a much higher reactivity with respect to the $\mathrm{HO}^{*}$ yield was observed for tetrahedral Fe than for octahedral Fe precipitates. The reason for the high redox reactivity of $\mathrm{Fe}^{3+}$ tet in silicates (and potentially Fe (hydr)oxide minerals) has, to our knowledge, not yet been examined.

\section{Active sites of $\mathrm{HO}^{\circ}$ generation by structural and external Fe on chrysotile surfaces}

Contrary to $\mathrm{Fe}$ addition to blank-altered fibers, $\mathrm{Fe}$ addition to DFOB-altered fibers clearly increased $\mathrm{HO}^{*}$ generation by chrysotile (Fig. 5a). Since DFOB-altered fibers were significantly depleted in $\mathrm{Fe}^{3+}$ tet sites, this suggests that upon $\mathrm{Fe}$ addition, $\mathrm{Fe}$ was incorporated into vacancy sites in the $\mathrm{Si}$ layer of DFOB-altered fiber surfaces where it became tetrahedrally coordinated and particularly active in $\mathrm{HO}^{*}$ generation. It should be noted, however, that Mössbauer data seem to indicate that addition of $3 \mu \mathrm{mol} \mathrm{g}{ }^{-1}{ }^{57} \mathrm{Fe}$ only resulted in a small increase of $\mathrm{Fe}^{3+}$ tet; only $3.0 \%$ of the $\mathrm{Fe}^{3+}$ tet removed in the DFOB pretreatment was recovered through Fe addition. $\mathrm{HO}^{*}$ generation, however, recovered to a substantially larger extent by $3 \mu \mathrm{mol} \mathrm{g}{ }^{-1}$ Fe addition: 10 percentage points relative to untreated fibers, corresponding to $19 \%$ of the difference between the blank-altered $+0 \mu \mathrm{mol} \mathrm{g}^{-1}$ Fe treatment (with the pristine $\mathrm{Fe}^{3+}{ }_{\text {tet }}$ content) and the DFOB-altered $+0 \mu \mathrm{mol} \mathrm{g}^{-1} \mathrm{Fe}$ treatment (with $\mathrm{Fe}^{3+}$ tet mostly depleted).

The limited recovery of $\mathrm{Fe}^{3+}{ }_{\text {tet }}$ by $3 \mu \mathrm{mol} \mathrm{g}{ }^{-1}{ }^{57} \mathrm{Fe}$ addition may be related to the observed enhanced Si dissolution, possibly creating vacancy sites in the Si layer and subsequent edge pit formation. Edge pit formation would make the sites unsuitable for accommodating $\mathrm{Fe}^{3+}$ tet coordination when the ${ }^{57} \mathrm{Fe}$ was added. However, the factor six discrepancy between recovered $\mathrm{Fe}^{3+}$ tet and recovered $\mathrm{HO}^{\circ}$ generation seems to indicate that recovered $\mathrm{Fe}^{3+}{ }_{\text {tet }}$ sites may be underestimated by Mössbauer data. Indeed, the recovery of $\mathrm{Fe}^{3+}{ }_{\text {tet }}$ sites was calculated under the assumption that no Fe-isotope exchange occurred in these sites over the timescales of the experiment. Considering the significant time gap between ${ }^{57} \mathrm{Fe}$ addition and Mössbauer spectroscopy, it is conceivable that isotope exchange reactions did occur over the timescales of the experiment. In this case, we may have under-estimated the increase of $\mathrm{Fe}^{3+}{ }_{\text {tet }}$ sites after addition of ${ }^{57} \mathrm{Fe}$. Finally, the reactivity of $\mathrm{Fe}^{3+}{ }_{\text {tet }}$ sites regarding $\mathrm{HO}^{*}$ generation may be heterogeneous as a result of differences in local coordination environment and the recovery of such sites may not be linearly related to the recovery of reactivity.

Blank-altered fibers do not have vacancy sites in the $\mathrm{Si}$ layer, and therefore addition of Fe did not lead to a clear increase in $\mathrm{HO}^{*}$ yield. However, the $\mathrm{HO}^{\circ}$ yield of the blank-altered $+0 \mu \mathrm{mol} \mathrm{g}^{-1}$ Fe treatment, in which surface $\mathrm{Fe}^{3+}{ }_{\text {tet }}$ was preserved, was still higher than the $\mathrm{HO}^{*}$ yield of fibers from the DFOB-altered $+300 \mu \mathrm{mol} \mathrm{g}^{-1} \mathrm{Fe}$ treatment. This suggests fewer exposed $\mathrm{Fe}^{3+}$ tet surface sites in the latter treatment, potentially as a result of a loss of vacancy sites due to ongoing dissolution of the Si layer.

Assuming that $\mathrm{Fe}$ addition to blank-altered fibers mainly lead to precipitation of Fe (hydr)oxide minerals, the lack of differences in $\mathrm{HO}^{*}$ yield between blankaltered fiber treatments with different amounts of added Fe suggests that these Fe (hydr)oxide minerals do not contribute to $\mathrm{HO}^{*}$ generation. This corresponds with results from previous studies: the $\mathrm{HO}^{\circ}$ yield of hematite, which contains no $\mathrm{Fe}^{3+}$ tet [54], was below the LOD in a study by Fubini et al. (1995) [37], while the $\mathrm{HO}^{\circ}$ yield of magnetite, which does contain structural $\mathrm{Fe}^{3+}{ }_{\text {tet }}$ [54], 
corresponded with $60 \%$ of the $\mathrm{HO}^{\circ}$ yield of chrysotile asbestos on a per mass basis [37]. The difference in reactivity between $\mathrm{Fe}^{3+}$ tet and octahedral $\mathrm{Fe}$ was larger for $\mathrm{HO}^{*}$ generation than for $\mathrm{H}_{2} \mathrm{O}_{2}$ decomposition.

The high Fenton reactivity of $\mathrm{Fe}^{3+}$ tet in chrysotile may, analogously to $\mathrm{H}_{2} \mathrm{O}_{2}$ decomposition, be explained by the lower redox potential of $\mathrm{Fe}^{3+}{ }_{\text {tet }}$ compared to octahedral $\mathrm{Fe}$, as observed in nontronites [55-57], and a potentially rapid back-oxidation of the Fenton-active $\mathrm{Fe}^{2+}{ }_{\text {tet }}$ to $\mathrm{Fe}^{3+}$ tet by $\mathrm{H}_{2} \mathrm{O}_{2}$, yielding $\mathrm{HO}^{*}$. In contrast to $\mathrm{Mg}$ and $\mathrm{Si}$ mobilization and $\mathrm{H}_{2} \mathrm{O}_{2}$ decomposition, addition of $30 \mu \mathrm{mol} \mathrm{g}^{-1} \mathrm{Fe}$ to DFOB-altered fibers did not recover the $\mathrm{HO}^{\circ}$ yield to the level of blank-altered fibers. For DFOB-altered fibers $+300 \mu \mathrm{mol} \mathrm{g}^{-1}$ Fe the $\mathrm{HO}^{*}$ yield $(37 \pm 14 \%)$ was still significantly lower than for blankaltered fiber $+0 \mu \mathrm{mol} \mathrm{L}^{-1}$ treatment $(58 \pm 6 \%$ ) (Fig. 5, Additional file 1: Table S5). This incomplete recovery of the Fenton reactivity when adding an excess of Fe may suggest a loss of vacancy sites during preconditioning e.g. due to edge pit formation, leading to a smaller number of $\mathrm{Fe}^{3+}$ tet surface sites than in the blank-altered fiber treatment.

\section{Conclusions}

The results from this study demonstrate that both $\mathrm{Fe}^{3+}{ }_{\text {oct }}$ in $\mathrm{Fe}$ (hydr)oxide precipitates and $\mathrm{Fe}^{3+}$ tet contribute to $\mathrm{H}_{2} \mathrm{O}_{2}$ decomposition by chrysotile asbestos; for asbestos fibers incubated at pH 7.4 in absence of a ligand (blank-altered) the contributions of both Fe species were comparable (within a factor 1.5), despite the excess of octahedral sites. A remnant mode of $\mathrm{H}_{2} \mathrm{O}_{2}$ decomposition by chrysotile was identified, which may be related to magnetite impurities, redox active substituted trace metals not removed by DFOB during pretreatment and remnant $\mathrm{Fe}$. $\mathrm{HO}^{\circ}$ generation by chrysotile asbestos is likely governed by $\mathrm{Fe}^{3+}{ }_{\text {tet; }}$ t the contribution from Fe precipitates is negligible.

The occurrence of $\mathrm{Fe}^{3+}$ tet in Fe (hydr)oxide minerals may also be correlated with their $\mathrm{HO}^{\circ}$ yield and their $\mathrm{H}_{2} \mathrm{O}_{2}$ decomposition capacity. However, whereas Fe (hydr)oxide minerals are not pathogenic [58], many silicate minerals other than chrysotile are. In many pathogenic silicates $\mathrm{Fe}^{3+}$ tet has been detected, e.g. in quartz, in amphiboles and in zeolites [59-64]. Even if these minerals do not contain $\mathrm{Fe}$, our results demonstrate that the presence of vacancy sites in their Si lattice can pose a risk, because incorporation of external Fe into the tetrahedral coordination environment can lead to $\mathrm{HO}^{*}$ generation. This may be particularly relevant for zeolites (e.g. erionite), which often have a non-detectable bulk Fe content, but a higher potential to induce mesothelioma than asbestos [2]. The dissolution of tetrahedral $\mathrm{Al}$ (which is a stoichiometric constituent of framework silicates) may create abundant vacancy sites in the Si lattice of zeolite fibers, available for the incorporation of Fenton-active tetrahedrally coordinated Fe.

To conclude, our results suggest that $\mathrm{Fe}^{3+}{ }_{\text {tet }}$ governs $\mathrm{HO}^{*}$ generation by chrysotile at circumneutral $\mathrm{pH}$, and that $\mathrm{Fe}^{3+}$ tet may also contribute to the hazard of other pathogenic silicates.

\section{Supplementary information}

Supplementary information accompanies this paper at https://doi.org/10. 1186/s12989-019-0333-1.

\begin{abstract}
Additional file1: Figure S1. Wide velocity range Mössbauer spectra of DFOB-altered fibers (Panel $a$ and c) and blank-altered fibers (Panel b and d) with 0 or $3 \mu \mathrm{mol} \mathrm{g}{ }^{-1}$ added ${ }^{57} \mathrm{Fe}$. Figure S2. Preconditioned fibers. Panel a.) From left to right: blank-altered fibers $+0 \mu \mathrm{mol} \mathrm{g}^{-1} \mathrm{Fe}$, blankaltered fibers $+3 \mu \mathrm{mol} \mathrm{g}{ }^{-1} \mathrm{Fe}$, blank-altered fibers $+30 \mu \mathrm{mol} \mathrm{g}{ }^{-1} \mathrm{Fe}$ and blank-altered fibers $+300 \mu \mathrm{mol} \mathrm{g}^{-1} \mathrm{Fe}$; Panel b.) Fiber preparation for Mössbauer analyses, from left to right: blank-altered fibers $+3 \mu \mathrm{mol} \mathrm{g}$ ${ }^{57} \mathrm{Fe}$, blank-altered fibers $+0 \mu \mathrm{mol} \mathrm{g}{ }^{-157} \mathrm{Fe}$, DFOB-altered fibers $+0 \mu \mathrm{mol}$ $\mathrm{g}^{-157} \mathrm{Fe}$, blank-altered fibers $+3 \mu \mathrm{mol} \mathrm{g}^{-157} \mathrm{Fe}$. Table S1. Mobilized Mg, $\mathrm{Si}$ and Fe concentrations in $\mu \mathrm{mol} \mathrm{L^{-1 }}$ during pretreatment (no duplicates available). Table S2. Mössbauer hyperfine parameters of DFOB-altered and blank-altered fibers +0 or $3 \mu \mathrm{mol} \mathrm{g}^{-157} \mathrm{Fe}$, analyzed in the narrow (Table a) and the wide (Table b) velocity range. The Fe species distributions were calculated from both the wide and the narrow velocity range data combined (see materials and methods) and are presented in Table c. Table S3. Mobilized Mg and Si concentrations from $1 \mathrm{~g} \mathrm{~L}^{-1}$ pristine, DFOB-altered and blank-altered fibers incubated at pH 7.4 (50 mM MOPS) with addition of $3.34 \mathrm{~g} \mathrm{~L}^{-1} \mathrm{H}_{2} \mathrm{O}_{2}$. Table S4. Residual $\mathrm{H}_{2} \mathrm{O}_{2}$ concentrations during $\mathrm{H}_{2} \mathrm{O}_{2}$ decomposition by pristine fibers, DFOB-altered fibers, blankaltered fibers and the MOPS buffer as a function of time. Table S5. $\mathbf{H O}^{*}$ yield of DFOB-altered and blank-altered fibers relative to pristine fibers (i.e. 100\%). Table S6. Results from the statistical analysis of the EPR spin trapping data presented in Fig. 5: $p$-values from the univariate general linear model and Tukey post-hoc test procedure. Table S7. Changes in ${ }^{57} \mathrm{Fe}$ and total Fe speciation upon addition of $3 \mu \mathrm{mol} \mathrm{g}{ }^{-1}{ }^{57} \mathrm{Fe}$ to blank-altered and DFOB-altered chrysotile at pH 7.4, as determined by Mössbauer spectroscopy. Table S8. Mobilized Mg and Si concentrations from $1 \mathrm{~g} \mathrm{~L}^{-1}$ pristine and blank altered fibers incubated in a $0.1 \mathrm{~mol} \mathrm{~L}^{-1} \mathrm{NaOH}$ solution with addition of $3.34 \mathrm{~g} \mathrm{~L}^{-1} \mathrm{H}_{2} \mathrm{O}_{2}$.
\end{abstract}

\section{Abbreviations}

ANOVA: Analysis of variance; BET: Brunauer, Emmet, Teller;

DFOB: Desferrioxamine-B; DMPO: 5-5-dimethyl-1-pyrroline N-oxide; DMPOHO: Adduct of DMPO and HO; DNA: Deoxyribonucleic acid; EPR: Electron paramagnetic resonance; $\mathrm{Fe}^{2+}{ }_{\text {oct }}$ : Ferrous octahedral $\mathrm{Fe} ; \mathrm{Fe}^{2+}{ }_{\text {tet: }}$ Ferrous tetrahedral Fe; $\mathrm{Fe}^{3+}$ oct: Ferric octahedral Fe; $\mathrm{Fe}^{3+}$ tet: Ferric tetrahedral Fe; FeDFOB: Fe complexed by DFOB; HEPES: 4-(2-hydroxyethyl)-1-

piperazineethanesulfonic acid; ICP-MS: Inductively coupled plasma mass spectrometry; ICP-OES: Inductively coupled plasma optical emission spectrometry; Ipp: Intensity peak-to-peak; LOD: Limit of detection; MOPS: 3(N-morpholino) propanesulfonic-acid; NAA: Neutron activation analysis; nvr: narrow velocity range; PP: Polypropylene; RPM: Rounds per minute; SSA: Specific surface area; Turkeys HSD test: Turkeys honestly significant difference test; UV-VIS: Ultra violet and visible light; WHO-IARC: World health organization, international agency for research on cancer; wvr: wide velocity range; XRD: X-ray diffraction

\section{Acknowledgements}

The authors would like to thank Dip.-Ing. Herwig Lenitz BSc and Ing. Wolfgang Obermaier for technical support, Dr. Carolina Reyes, Dr. Jerry van Dijk and Dr. Angeles Garcia Mayor for their help with the statistical analysis and Kyounglim Kang MSc for the synthesis of the 2-line ferrihydrite.

\section{Authors' contribution}

MW developed the ideas for the present study, planned and carried out all experiments, did the analysis of all obtained data (apart from Mössbauer) and drafted the manuscript; WS co-supervised the project, contributed to 
conceptualization and interpretation of the experimental data, and corrected and co-wrote the manuscript; GG performed and LG designed and performed EPR experiments; MR performed and analyzed the Mössbauer experiments; SK supervised this project and particularly participated in project development, interpretation of observations and manuscript preparation. All authors read and approved the final manuscript.

\section{Funding}

This research was funded by an uni:docs scholarship of the University of vienna.

\section{Availability of data and materials}

The datasets generated and/or analyzed during the current study are available in the supplementary information repository, https://doi.org/10. 1186/s12989-019-0333-1. The dataset supporting the conclusions of this article is included within the article (and its additional file).

\section{Ethics approval and consent to participate}

Not applicable.

\section{Consent for publication}

Not applicable.

\section{Competing interests}

The authors declare that they have no competing interests.

\section{Author details}

${ }^{1}$ Department of Environmental Geosciences, University of Vienna, Althanstraße 14 (UZA II), 1090 Vienna, Austria. ${ }^{2}$ Copernicus Institute of Sustainable Development, Faculty of Geosciences, Utrecht University, Princetonlaan 8A, 3584, CB, Utrecht, the Netherlands. ${ }^{3}$ Institute of Pharmacology and Toxicology, University of Veterinary Medicine, Veterinärplatz 1, 1210 Vienna, Austria. ${ }^{4}$ Institute of Solid State Physics, TU Wien, Wiedner Hauptstraße 8-10, 1040 Vienna, Austria.

Received: 4 September 2019 Accepted: 23 December 2019 Published online: 20 January 2020

\section{References}

1. Catherine $\mathrm{H}$, Skinner W. Mineralogy of asbestos minerals. Indoor Built Environ. 2003;12(6):385-9. https://doi.org/10.1177/1420326x03037003.

2. Hardy JA, Aust AE. Iron in asbestos chemistry and carcinogenicity. Chem Rev. 1995;95(1):97-118. https://doi.org/10.1021/cr00033a005.

3. Frank A. The History of the Extraction and Uses of Asbestos; 2005. p. 1-7. https://doi.org/10.1201/9781420038149.ch1.

4. Asbestos (chrysotile, amosite, crocidolite, tremolite, actinolite, and anthophyllite), IARC Monographs on the Evaluation of Carcinogenic Risks to Humans 100C, International Agency for Research on Cancer. 2012.

5. Olsen NJ, Franklin P, Reid A, Klerk N, Threlfall TJ, Shilkin K, et al. Increasing incidence of malignant mesothelioma after exposure to asbestos during home maintenance and renovation. Med J Australia. 2011;195:271-4. https://doi.org/10.5694/mja11.10125.

6. Baur X. Asbestos: socio-legal and scientific controversies and unsound science in the context of the worldwide Asbestos tragedy - lessons to be learned. Pneumologie. 2016;70(6):405-12. https://doi.org/10.1055/s-0042103580

7. Kamp DW, Weitzman SA. The molecular basis of asbestos induced lung injury. Thorax. 1999;54(7):638-52. https://doi.org/10.1136/thx.54.7.638.

8. WHO-IARC. Arsenic, metals, fibres and dusts. IARC monographs on the evaluation of carcinogenic risks to humans, vol. 100 C; 2012. p. 219-94.

9. $\mathrm{WHO}$, International programme on chemical safety: Chrysotile asbestos, ISBN: 978924156481 6. 2014.

10. Nishikawa K, Takahashi K, Karjalainen A, Wen CP, Furuya S, Hoshuyama T, et al. Recent mortality from pleural mesothelioma, historical patterns of Asbestos use, and adoption of bans: a global assessment. Environ Health Perspect. 2008;116(12):1675-80. https://doi.org/10.1289/ehp.11272.

11. Le GV, Takahashi K, Park EK, Delgermaa V, Oak C, Qureshi AM, et al. Asbestos use and asbestos-related diseases in Asia: past, present and future. Respirology. 2011;16(5):767-75. https://doi.org/10.1111/j.1440-1843.2011. 01975.x.
12. Nicholson WJ. The carcinogenicity of chrysotile asbestos - a review. Ind Health. 2001;39(2):57-64. https://doi.org/10.2486/indhealth.39.57.

13. Landrigan PJ. Asbestos - Still a carcinogen. N Engl J Med. 1998;338(22): 1618-9. https://doi.org/10.1056/nejm199805283382209.

14. Bales RC, Morgan JJ. Surface-charge and adsorption properties of chrysotile asbestos in natural-waters. Environ Sci Technol. 1985;19(12):1213-9. https:// doi.org/10.1021/es00142a013.

15. Evans BW. The serpentinite multisystem revisited: Chrysotile is metastable. Int Geol Rev. 2004;46(6):479-506. https://doi.org/10.2747/0020-6814.46.6.479.

16. Bowes DR, Farrow CM. Major and trace element compositions of the UICC standard asbestos samples. Am J Ind Med. 1997;32(6):592-4. https://doi.org/ 10.1002/(sici)1097-0274(199712)32:6<592::aid-ajim3>3.0.co;2-s.

17. Ristic M, Czako-Nagy I, Music S, Vertes A. Spectroscopic characterization of chrysotile asbestos from different regions. J Mol Struct. 2011;993(1-3):120-6. https://doi.org/10.1016/j.molstruc.2010.10.005.

18. Stroink G, Blaauw C, White CG, Leiper W. Mössbauer characteristics of UICC* standard reference asbestos samples. Can Mineral. 1980;18:285-90 <Go to |S|>://WOS:000208518700004.

19. Gronow JR. The dissolution of asbestos fibers in water. Clay Miner. 1987; 22(1):21-35. https://doi.org/10.1180/claymin.1987.022.1.03.

20. Bales RC, Morgan JJ. Dissolution kinetics of chrysotile at $\mathrm{pH}=7$ to 10 . Geochim Cosmochim Acta. 1985;49(11):2281-8. https://doi.org/10.1016/ 0016-7037(85)90228-5.

21. Walter M, Schenkeveld WDC, Reissner M, Gille L, Kraemer SM. The Effect of $\mathrm{pH}$ and Biogenic Ligands on the Weathering of Chrysotile Asbestos: The Pivotal Role of Tetrahedral Fe in Dissolution Kinetics and Radical Formation. Chem Eur J. 2019;25:3386. https://doi.org/10.1002/chem.201804319.

22. Mossman BT, Churg A. Mechanisms in the pathogenesis of asbestosis and silicosis. Am J Respir Crit Care Med. 1998;157(5):1666-80.

23. Churg A. Deposition and clearance of chrysotile asbestos. Ann Occup Hyg. 1994;38(4):625-33. https://doi.org/10.1093/annhyg/38.4.625.

24. Winterbourn CC. Toxicity of iron and hydrogen peroxide: The Fenton reaction. Toxicol Lett. 1995;82:969-74. https://doi.org/10.1016/0378-4274(95)03532-x.

25. Kamp DW, Graceffa P, Pryor WA, Weitzman SA. The role of free-radicals in asbestos-induced diseases. Free Radic Biol Med. 1992;12(4):293-315. https:// doi.org/10.1016/0891-5849(92)90117-y.

26. Gazzano E, Turci F, Foresti E, Putzu MG, Aldieri E, Silvagno F, et al. Ironloaded synthetic chrysotile: a new model solid for studying the role of iron in asbestos toxicity. Chem Res Toxicol. 2007;20(3):380-7. https://doi.org/10. $1021 / \mathrm{t} \times 600354 \mathrm{f}$.

27. Fenoglio I, Prandi L, Tomatis M, Fubini B. Free radical generation in the toxicity of inhaled mineral particles: the role of iron speciation at the surface of asbestos and silica. Redox Rep. 2001;6(4):235-41. https://doi.org/10.1179/ 135100001101536382

28. Haber F, Weiss J. Über die Katalyse des Hydroperoxydes. Naturwissenschaften. 1932;20(51):948-50.

29. De Laat J, Gallard H. Catalytic decomposition of hydrogen peroxide by Fe (III) in homogeneous aqueous solution: mechanism and kinetic modeling. Environ Sci Technol. 1999;33(16):2726-32. https://doi.org/10.1021/es981171v.

30. Eberhardt MK, Román-Franco AA, Quiles MR. Asbestos-induced decomposition of hydrogen peroxide. Environ Res. 1985;37(2):287-92. https://doi.org/10.1016/0013-9351(85)90108-2.

31. Fubini B, Mollo L, Giamello E. Free-radical generation at the solid/liquid interface in iron-containing minerals. Free Radic Res. 1995;23(6):593-614. https://doi.org/10.3109/10715769509065280

32. Ghio A, Taylor DE, Stonehuerner JG, Piantadosi CA, Crumbliss AL. The release of iron from different asbestos structures by hydrogen peroxide with concomitant O2 generation. Biometals. 1998;11/1:41-7. https://doi.org/ 10.1023/A:1009257323963.

33. Weitzman SA, Graceffa P. Asbestos catalyzes hydroxyl and superoxide radical generation from hydrogen-peroxide. Arch Biochem Biophys. 1984; 228(1):373-6. https://doi.org/10.1016/0003-9861(84)90078-x.

34. Ghio AJ, Kennedy TP, Stonehuerner JG, Crumbliss AL, Hoidal JR. DNA strand breaks following in-vitro exposure to asbestos increase with surface complexed Fe3+. Arch Biochem Biophys. 1994;311(1):13-8. https://doi.org/10.1006/abbi.1994.1202.

35. Ghio AJ, Kennedy TP, Whorton AR, Crumbliss AL, Hatch GE, Hoidal JR. Role of surface complexed iron in oxidant generation and lung inflammation induced by silicates. Am J Phys. 1992;263(5):L511-L8.

36. Ghio AJ, LeFurgey A, Roggli VL. In vivo accumulation of iron on crocidolite is associated with decrements in oxidant generation by the fiber. J Toxicol Environ Health. 1997;50(2):125-42. 
37. Fubini B, Mollo L. Role of iron in the reactivity of mineral fibers. Toxicol Lett. 1995;82-3:951-60. https://doi.org/10.1016/0378-4274(95)03531-1.

38. Aust AE, Cook PM, Dodson RF. Morphological and chemical mechanisms of elongated mineral particle toxicities. J Toxicol Environ Health-Part B-Crit Rev. 2011;14(1-4):40-75. https://doi.org/10.1080/10937404.2011.556046.

39. Kandegedara A, Rorabacher DB. Noncomplexing tertiary amines as "better" buffers covering the range of $\mathrm{pH} 3-11$. Temperature dependence of their acid dissociation constants. Anal Chem. 1999;71 15:3140-4. https://doi.org/ 10.1021/ac9902594.

40. Doulias PT, Christoforidis S, Brunk UT, Galaris D. Endosomal and lysosomal effects of desferrioxamine: protection of HeLa cells from hydrogen peroxide-induced DNA damage and induction of cell-cycle arrest. Free Radic Biol Med. 2003;35(7):719-28. https://doi.org/10.1016/s08915849(03)00396-4.

41. Geroldinger $\mathrm{G}$, Tonner M, Hettegger H, Bacher M, Monzote L, Walter M, et al. Mechanism of ascaridole activation in Leishmania. Biochem Pharmacol. 2017;132:48-62. https://doi.org/10.1016/j.bcp.2017.02.023.

42. ThomasArrigo LK, Mikutta C, Byrne J, Kappler A, Kretzschmar R. Iron (II)catalyzed Iron atom exchange and mineralogical changes in Iron-rich organic freshwater Flocs: an Iron isotope tracer study. Environ Sci Technol. 2017:51(12):6897-907. https://doi.org/10.1021/acs.est.7b01495.

43. Stookey LL. Ferrozine---a new spectrophotometric reagent for iron. Anal Chem. 1970;42(7):779-81. https://doi.org/10.1021/ac60289a016.

44. Reay A. The effect of disk mill grinding on some rock-forming minerals. Mineral Mag. 1981;44(334):179-82. https://doi.org/10.1180/minmag.1981.044. 334.10.

45. Mørup S, Both E. Interpretation of Mossbauer-spectra with broadened lines. Nucl Inst Methods. 1975;124(2):445-8. https://doi.org/10.1016/0029554x(75)90595-9.

46. Murad E, Schwertmann U. The Mössbauer spectrum of ferrihydrite and its relations to those of other iron-oxides. Am Mineral. 1980;65(9-10):1044-9.

47. Eisenberg GM. Colorimetric determination of hydrogen peroxide. Ind Eng Chem-Anal Ed. 1943;15:327-8. https://doi.org/10.1021/i560117a011.

48. Zhao GH, Chasteen ND. Oxidation of Good's buffers by hydrogen peroxide. Anal Biochem. 2006;349(2):262-7. https://doi.org/10.1016/j.ab.2005.10.005.

49. Dominguez-Vera JM. Iron (III) complexation of Desferrioxamine B encapsulated in apoferritin. J Inorg Biochem. 2004;98(3):469-72. https://doi. org/10.1016/j.jinorgbio.2003.12.015.

50. Machala Z, Tarabova B, Hensel K, Spetlikova E, Sikurova L, Lukes P. Formation of ROS and RNS in Water Electro-Sprayed through Transient Spark Discharge in Air and their Bactericidal Effects: Formation of ROS/RNS in Water Sprayed through Spark in Air. Plasma Process Polym. 2013;10(7):649-59.

51. Favero-Longo S, Turci F, Tomatis M, Compagnoni R, Piervittori R, Fubini B. The effect of weathering on Ecopersistence, reactivity, and potential toxicity of naturally occurring Asbestos and Asbestiform minerals. J Toxicol Environ Health-Part A-Curr Issues. 2009;72(5):305-14. https://doi.org/10.1080/ 15287390802529864

52. Turci F, Favero-Longo SE, Tomatis M, Martra G, Castelli D, Piervittori R, et al. A biomimetic approach to the chemical inactivation of chrysotile fibres by lichen metabolites. Chem Eur J. 2007;13(14):4081-93. https://doi.org/10. 1002/chem.200600991.

53. Schwertmann U, Cornell RM. Iron oxides in the laboratory. 2., completely rev. and extended ed. edn. Weinheim: Wiley-VCH; 2000

54. Murad E, Cashion J. Mössbauer spectroscopy of environmental materials and their industrial utilization; 2004

55. Russell JD. Infrared and Mössbauer Studies of Reduced Nontronites. Clay Clay Miner. 1979;27(1):63-71. https://doi.org/10.1346/CCMN.1979.0270108.

56. Jaisi DP, Kukkadapu RK, Eberl DD, Dong H. Control of Fe (III) site occupancy on the rate and extent of microbial reduction of Fe (III) in nontronite. Geochim Cosmochim Acta. 2005;69(23):5429-40. https://doi.org/10.1016/j. gca.2005.07.008.

57. Merola RB, McGuire MM. Crystallographic site distribution and redox activity of Fe in nontronites determined by optical spectroscopy. Clay Clay Miner. 2009;57(6):771-8. https://doi.org/10.1346/CCMN.2009.0570609.

58. Steinhoff $D, M o h r ~ U$, Hahnemann $S$. Carcinogenesis studies with iron oxides. Exp Pathol. 1991;43(3):189-94. https://doi.org/10.1016/S0232-1513(11)80116-7.

59. Roquemalherbe R, Diazaguila C, Regueraruiz E, Fundoralliteras J, Lopezcolado L, Hernandezvelez M. The state of iron in natural zeolites - a Mossbauer study. Zeolites. 1990;10(7):685-9. https://doi.org/10.1016/01442449(90)90080-b.
60. Di Benedetto F, D'Acapito F, Fornaciai G, Innocenti M, Montegrossi G, Pardi LA, et al. A Fe K-edge XAS study of amethyst. Phys Chem Miner. 2010;37(5): 283-9. https://doi.org/10.1007/s00269-009-0332-0.

61. Weil JA. EPR of iron centers in silicon dioxide. Appl Magn Reson. 1994;6(12):1-16. https://doi.org/10.1007/BF03162478.

62. Dennen WH. Stoichiometric substitution in natural quartz. Geochim Cosmochim Acta. 1966;30 12:1235. https://doi.org/10.1016/00167037(66)90122-0.

63. Goldfarb D, Strohmaier KG, Vaughan DEW, Thomann H, Poluektov OG, Schmidt J. Studies of framework iron in zeolites by pulsed ENDOR at 95 GHz. J Am Chem Soc. 1996;118(19):4665-71. https://doi.org/10.1021/ ja953903e.

64. Luys M-J, De Roy GL, Adams F, Vansant EF. Cation site population in amphibole asbestos. A Mossbauer study. J Chem Soc Faraday Trans. 1983;79 6:1451-9. https://doi.org/10.1039/F19837901451.

\section{Publisher's Note}

Springer Nature remains neutral with regard to jurisdictional claims in published maps and institutional affiliations.

Ready to submit your research? Choose BMC and benefit from:

- fast, convenient online submission

- thorough peer review by experienced researchers in your field

- rapid publication on acceptance

- support for research data, including large and complex data types

- gold Open Access which fosters wider collaboration and increased citations

- maximum visibility for your research: over $100 \mathrm{M}$ website views per year

At $\mathrm{BMC}$, research is always in progress.

Learn more biomedcentral.com/submissions 